\title{
Rangewide Plan for Managing Habitat of Desert Bighorn Sheep on Public Lands
}

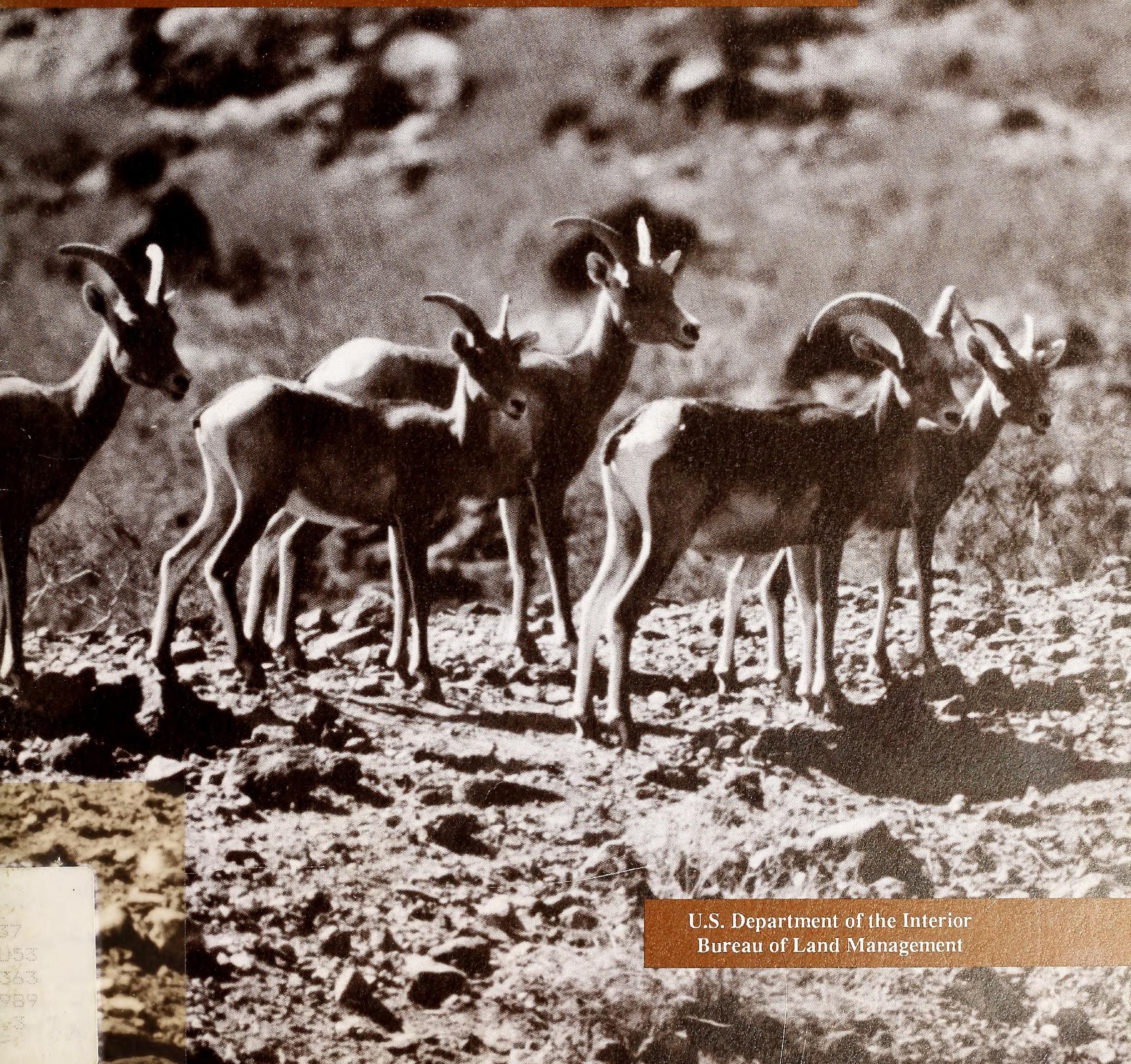




$$
\cdots
$$

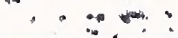

$\cdots$

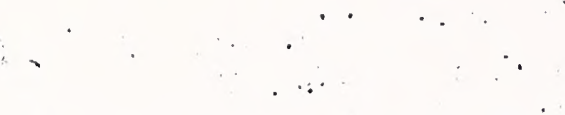

$\Rightarrow \quad \therefore \quad$. 


\section{BLM LIBRARY \\ SC.324A, BLDG. 50 \\ DENVER FEDERAL CENTER \\ P. O. BOX 25047 \\ DRAMER. CO 802?:Tr,047}

\section{Rangewide Plan \\ for Managing Habitat of \\ Desert Bighorn Sheep \\ on Public Lands}





\section{Contents}

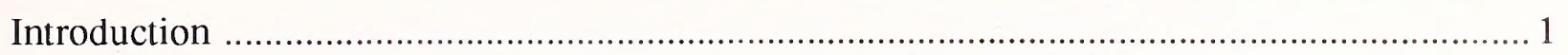

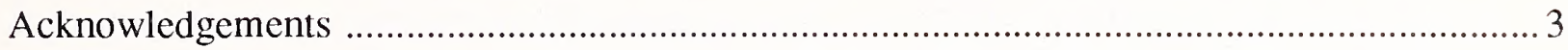

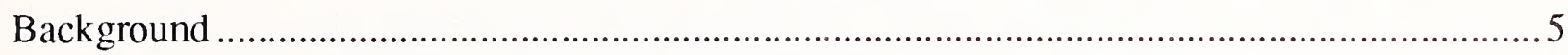

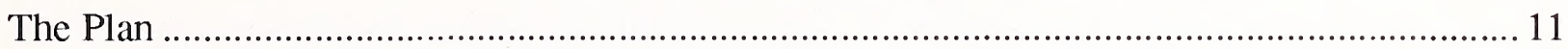

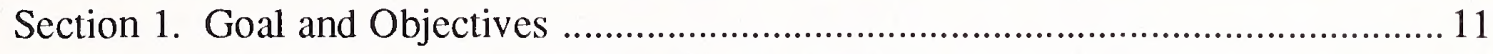

Section 2. Management Practices and Standards ..................................................... 17

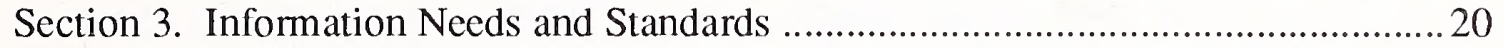

Future Activities, Plan Revisions, and Monitoring ........................................................ 23

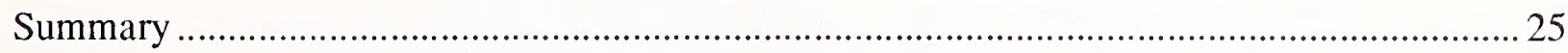

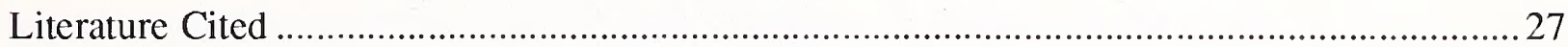

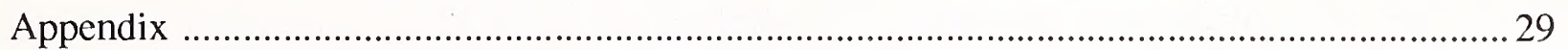





\section{Introduction}

The Desert Bighorn Management Plan provides guidance and sets priorities for a program to manage desert bighom sheep habitat on public lands administered by the Bureau of Land Management (BLM) in Arizona, California, Colorado, Nevada, New Mexico, and Utah. The goal of the program is to facilitate recovery of desert bighorn in the Southwest through a balanced program of inventory, on-the-ground projects, monitoring, and research. This program will be consistent with locally developed land-use plans. Numerous other wildlife species, many of which are threatened or endangered, will also benefit from this program.

This plan describes specific goals, objectives, and priorities of the program with regard to habitat areas, management practices, and information needs. More detailed information on actual projects, project costs, and locations are described in activity plans.

Resource Management Plans (RMPs) are developed by BLM with public participation to provide direction for management of Federal resources. RMPs are typically developed for Resource Areas, which may consist of several million acres. At this level, a management objective might be to manage habitat in a particular mountain range to maintain a viable population of desert bighom sheep. On-the- ground projects to achieve such objectives are specified in site-specific management plans, commonly termed "activity plans." These plans may target a specific land-use activity such as livestock grazing or several activities. Activity plans are usually developed for more local areas such as a mountain range of several thousand acres. Activity plans for wildlife are termed Habitat Management Plans (HMPs) in the BLM. At this planning level, an HMP might specify development of waters at three locations and prescribed burning for another area. These projects could support the overall RMP objective of maintaining a viable (self-sustaining) population of desert bighorn sheep.

This rangewide plan represents a third level of planning. It comprises a consolidation of desert bighorn sheep objectives in RMPs into rangewide objectives and priorities for the BLM. Thus, this rangewide plan has been developed from the ground up and is totally consistent with the more local RMPs. It is not a plan to override or supersede decisions made and objectives agreed upon through the normal land-use planning process. The rangewide plan thus provides for a coordinated and costeffective program to facilitate recovery of desert bighorn on BLM lands in the southwestern United States.

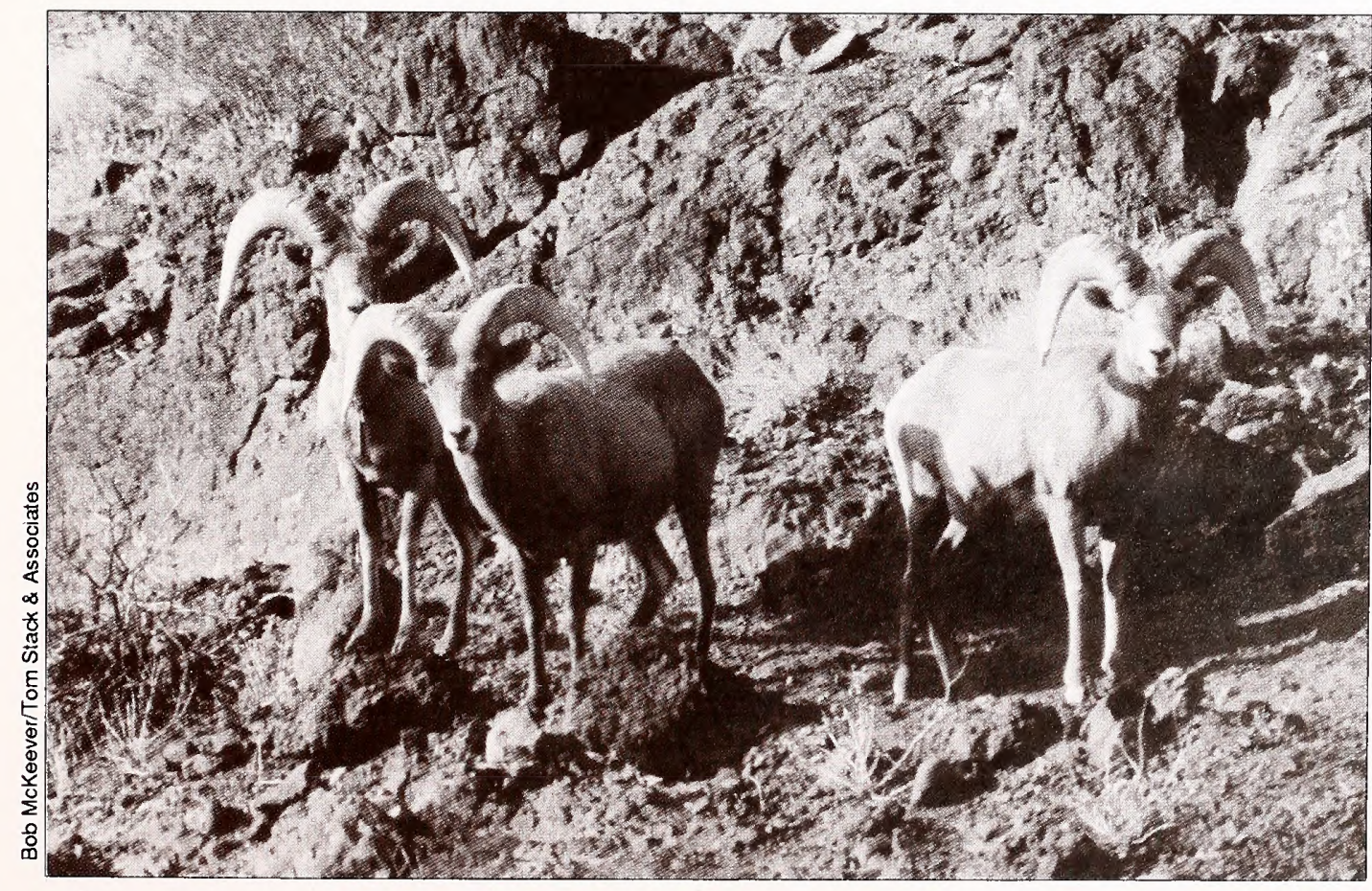

Nelson Bighorn (Ovis canadensis nelsoni) 



\section{Acknowledgments}

Recovery of desert bighorn has been and will continue to be a cooperative effort between many individuals, private organizations, and State and Federal agencies. In the case of the desert bighorn, the private sector has been particularly important. The BLM wishes to acknowledge the Arizona Desert Bighorn Sheep Society, the Fraternity of the Desert Bighorn, Nevada Bighorns Unlimited, the Society for the Conservation of Desert Bighorn, and the Foundation for North American Wild Sheep for their continuing support of this program in contributed funds, labor, and other services. The Desert Bighorn Council has promoted sound scientific management of desert bighorn and their habitat for many years, and the BLM appreciates their assistance and expertise in preparing and reviewing this plan. Finally the BLM wishes to express appreciation to the six State agencies, the Arizona Fish and Game Department, the California Fish and Game Department, the Colorado Division of Wildlife, the Nevada Department of Wildlife, the New Mexico Game and Fish Department, and the Utah Division of Wildlife Resources, for their assistance and expertise in preparing this plan and for their continued cooperation in the program.

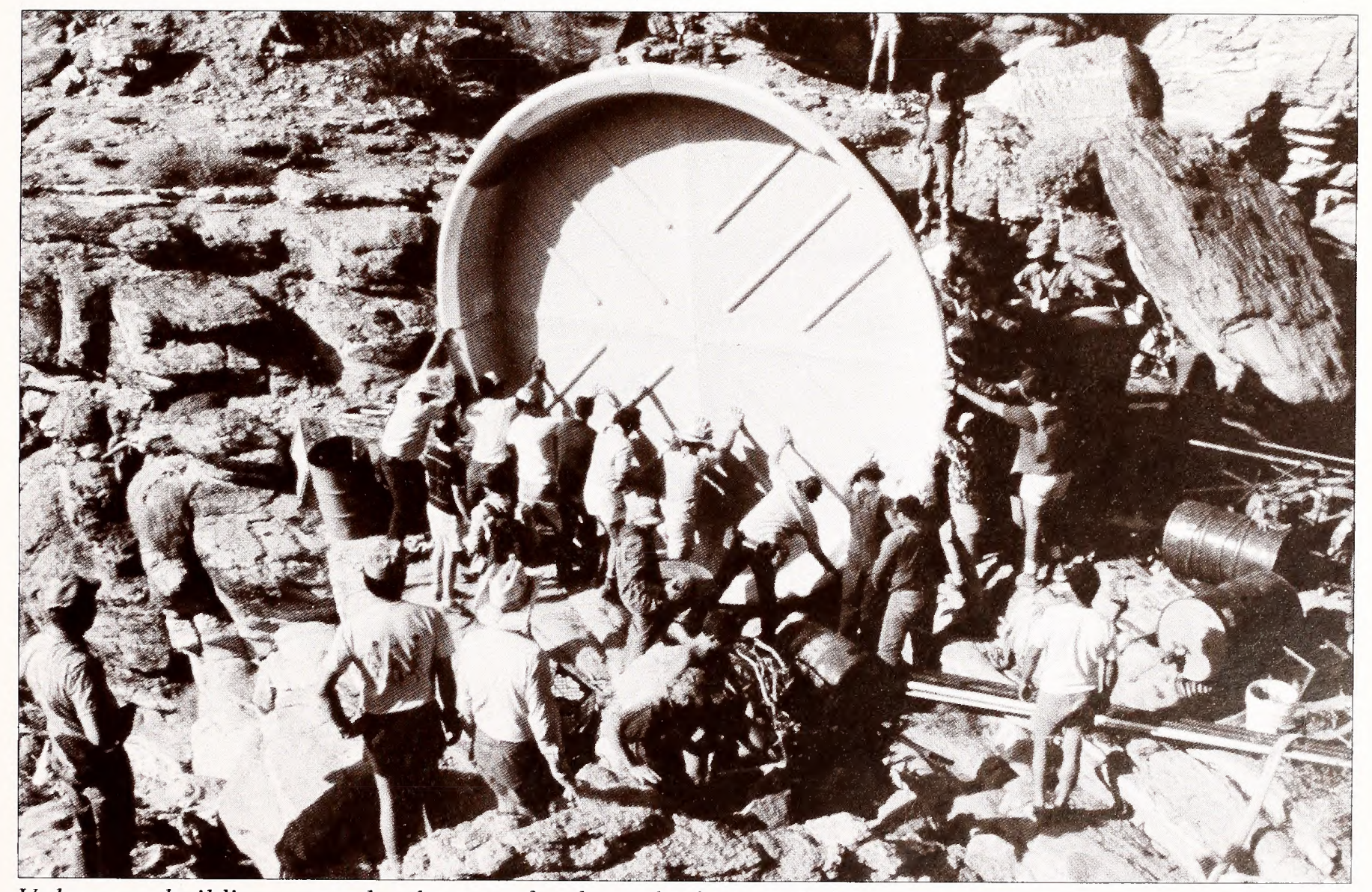

Volunteers building water development for desert bighorn in California. 



\section{Background}

Populations of desert bighorn sheep in the southwestern United States (Ovis canadensis subspecies cremnobates, mexicana, and nelsoni) have declined drastically since the early 1800s (Buechner 1960). Historic populations numbered in the hundreds of thousands. Today, desert bighorn numbers in the U.S. are approximately 16,000 (Weaver $1985 ;$ 1986). This decline has been attributed to several factors including exploitive hunting, disease, habitat destruction, competition from burros, and especially overgrazing by livestock. Legal hunting is no longer a cause of decline nor a factor preventing recovery (Kelly 1980), and some herds in areas where the habitat has recovered have begun to increase since around 1950 (Cooperrider 1985). Preservation and enhancement of habitat will thus be necessary for future recovery of desert bighorns (Cooperrider 1985; Wilson 1975).
About 80 percent of desert bighom sheep habitat is on Federal land, the majority of which is administered by BLM (Figures 1 and 2). The BLM administers roughly $8,800,000$ acres of desert bighorn habitat occupied by approximately 10,000 desert sheep. However, only 33 habitat areas on BLM lands support populations of at least 100 sheep and only 22 of these 33 herds consist of 125 animals or more. Populations of less than 125 are not considered viable by some biologists (Geist 1975:105). Therefore, the welfare of the desert bighorn is still precarious in the southwestern United States. However, BLM manages an additional 84 habitat areas that can support $100 \pm 20$ sheep (Table 1). Through habitat management and working closely with State wildlife agencies and wild sheep organizations, BLM can play a key role in facilitating the recovery of desert bighorn populations in North America be-

Table 1. Habitat areas on BLM lands with potential for supporting viable populations of desert bighorn sheep. ${ }^{1}$

\begin{tabular}{|c|c|c|c|c|c|c|c|c|c|c|c|c|c|}
\hline \multirow{2}{*}{\multicolumn{4}{|c|}{\begin{tabular}{|c|} 
Category I \\
$\begin{array}{c}\text { Habitat Areas with Existing } \\
\text { Viable Populations }\end{array}$
\end{tabular}}} & \multicolumn{4}{|c|}{ Category II } & \multicolumn{5}{|c|}{ Category III } & \multirow[b]{2}{*}{ Total } \\
\hline & & & & \multicolumn{4}{|c|}{$\begin{array}{l}\text { Habitat Areas with } \\
\text { Remnant Herds }{ }^{3}\end{array}$} & \multicolumn{5}{|c|}{$\begin{array}{l}\text { Unoccupied Habitat Areas Capable } \\
\text { of Supporting Viable Populations }{ }^{3}\end{array}$} & \\
\hline Arizona & 0 & 5 & 3 & 8 & 0 & 8 & 4 & 12 & 0 & 0 & 1 & 1 & 21 \\
\hline California & 1 & 0 & 8 & 9 & 1 & 0 & 17 & 18 & 0 & 0 & 0 & 0 & 27 \\
\hline Colorado & 0 & 0 & 0 & 0 & 0 & 1 & 3 & 4 & 0 & 0 & 2 & 2 & 6 \\
\hline Nevada & 0 & 0 & 9 & 9 & 0 & 0 & 14 & 14 & 0 & 0 & 15 & 15 & 38 \\
\hline New Mexico & 0 & 1 & 0 & 1 & 0 & 1 & 0 & 1 & 0 & 1 & 0 & 1 & 3 \\
\hline Utah & 0 & 0 & 6 & 6 & 0 & 0 & 9 & 9 & 0 & 0 & 5 & 5 & 20 \\
\hline Total & 1 & 6 & 26 & 33 & 1 & 10 & 47 & 58 & 0 & 1 & 23 & 24 & 115 \\
\hline
\end{tabular}

${ }^{1}$ A criteria of $100 \pm 20$ desert bighorn sheep is considered a viable population.

${ }^{2}$ A population must be estimated to have at least 100 sheep to be considered as an existing viable population.

${ }^{3}$ A habitat area must be estimated to have the capability of supporting at least 80 desert bighorn sheep to be listed. 


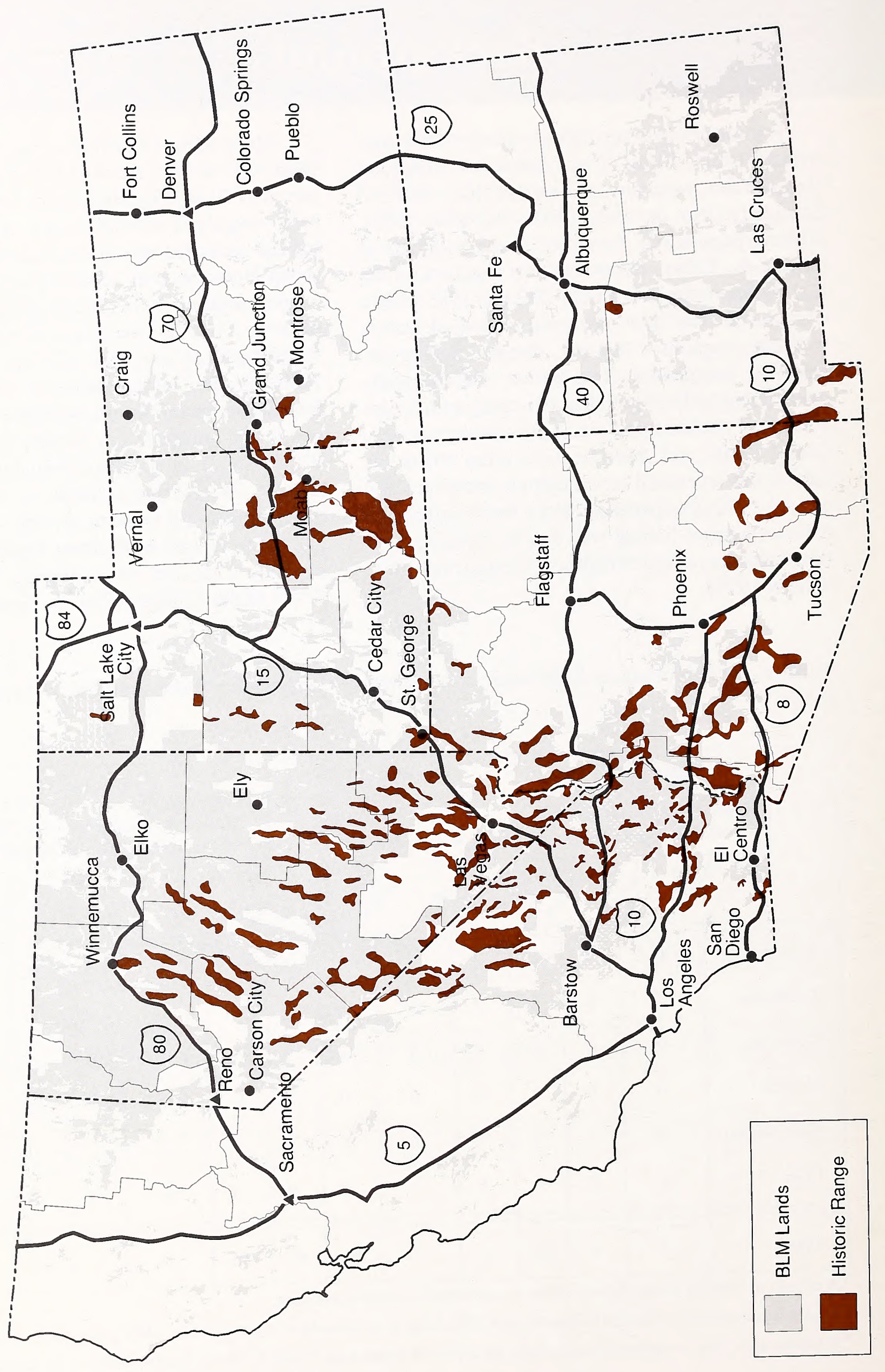




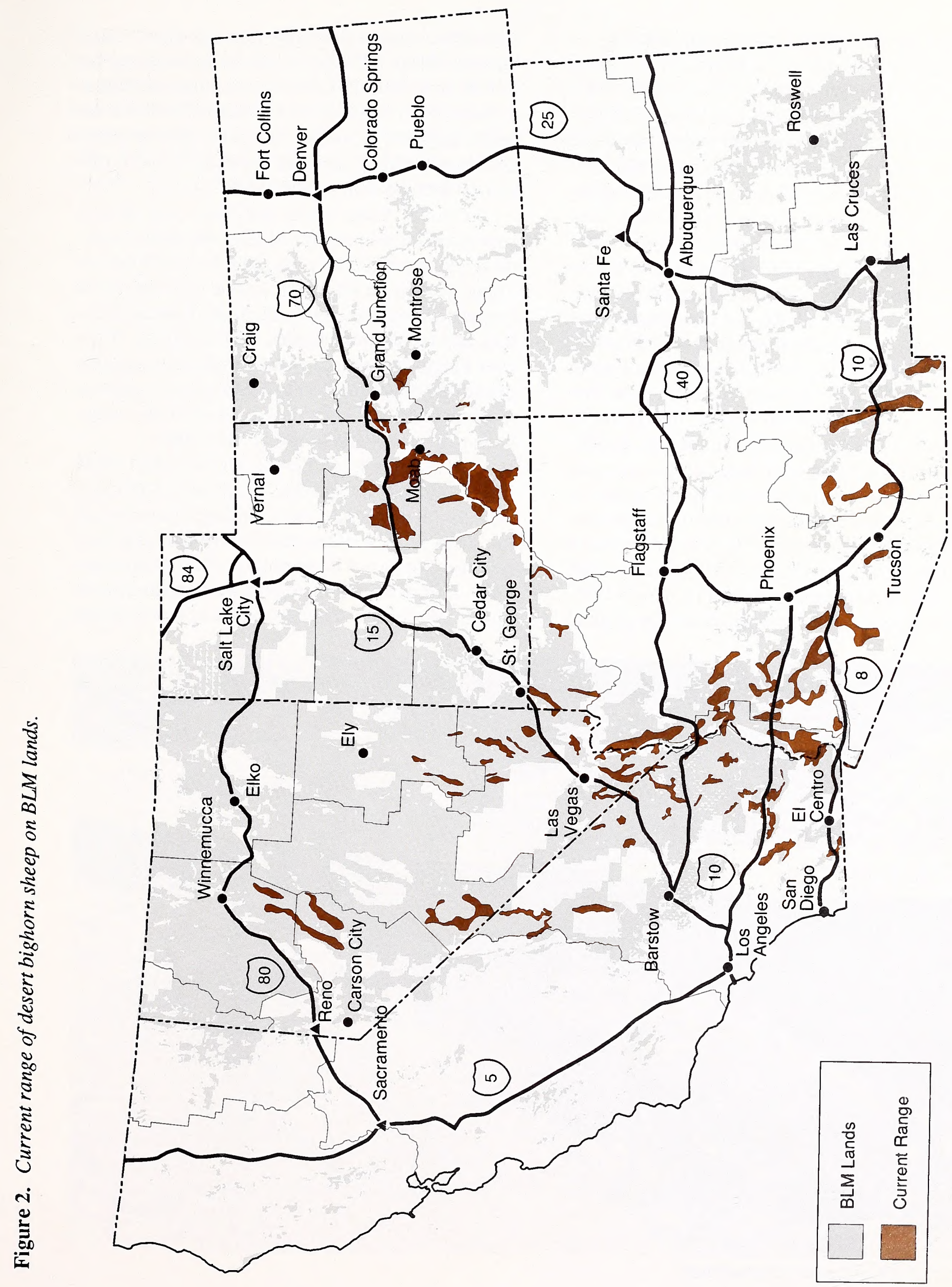


cause of the amount of habitat it administers.

BLM biologists and managers have been working with State wildlife agencies, private individuals, and conservation groups to enhance bighorn sheep habitat for over 20 years. However, recent events and increasing awareness and concern for desert bighorns have provided the opportunity to increase and strengthen this effort. The history of BLM's involvement in bighorn habitat management through 1985 is summarized below and described in more detail in Cooperrider(1986).

The experience of the last two decades has demonstrated that bighorn sheep habitat on public lands administered by the BLM can be managed to allow recovery of desert bighorn populations. The earliest work focused on habitat management, primarily water development. In the past decade, BLM has cooperated with State wildlife agencies to reintroduce sheep into their historic ranges. In many cases, these efforts have been quite successful. However, they continue to be a piecemeal or "herd-by-herd" approach to management, with little rangewide perspective. For Fiscal Year 1985, Congress provided BLM with a challenge grant of
$\$ 300,000$ to initiate a program for recovery of desert bighorn sheep. This grant was to be matched by private contributions of money or in-kind services. In Fiscal Year 1985, BLM spent over $\$ 900,000$ on desert bighorn, including the grant, base funding, and contributed monies and services. Most of this money was spent on project work.

In Fiscal Years 1986 and 1987, this special appropriation was continued with the same conditions and approximately the same level of funding. These funds were used for the same types of efforts (water development, reintroductions, habitat inventory and monitoring, studies, and research). However, a plan was needed to identify priorities and give overall funding direction to BLM's desert bighorn recovery program. Thus, development of this rangewide plan was begun in Fiscal Year 1986.

In 1986, the BLM Service Center asked BLM State Directors in Arizona, California, Colorado, Nevada, New Mexico, and Utah for information on the status of their desert bighorn habitats and their priorities for desert bighorn sheep habitat management. A draft management plan was prepared based on this information. The draft plan was sent to the six

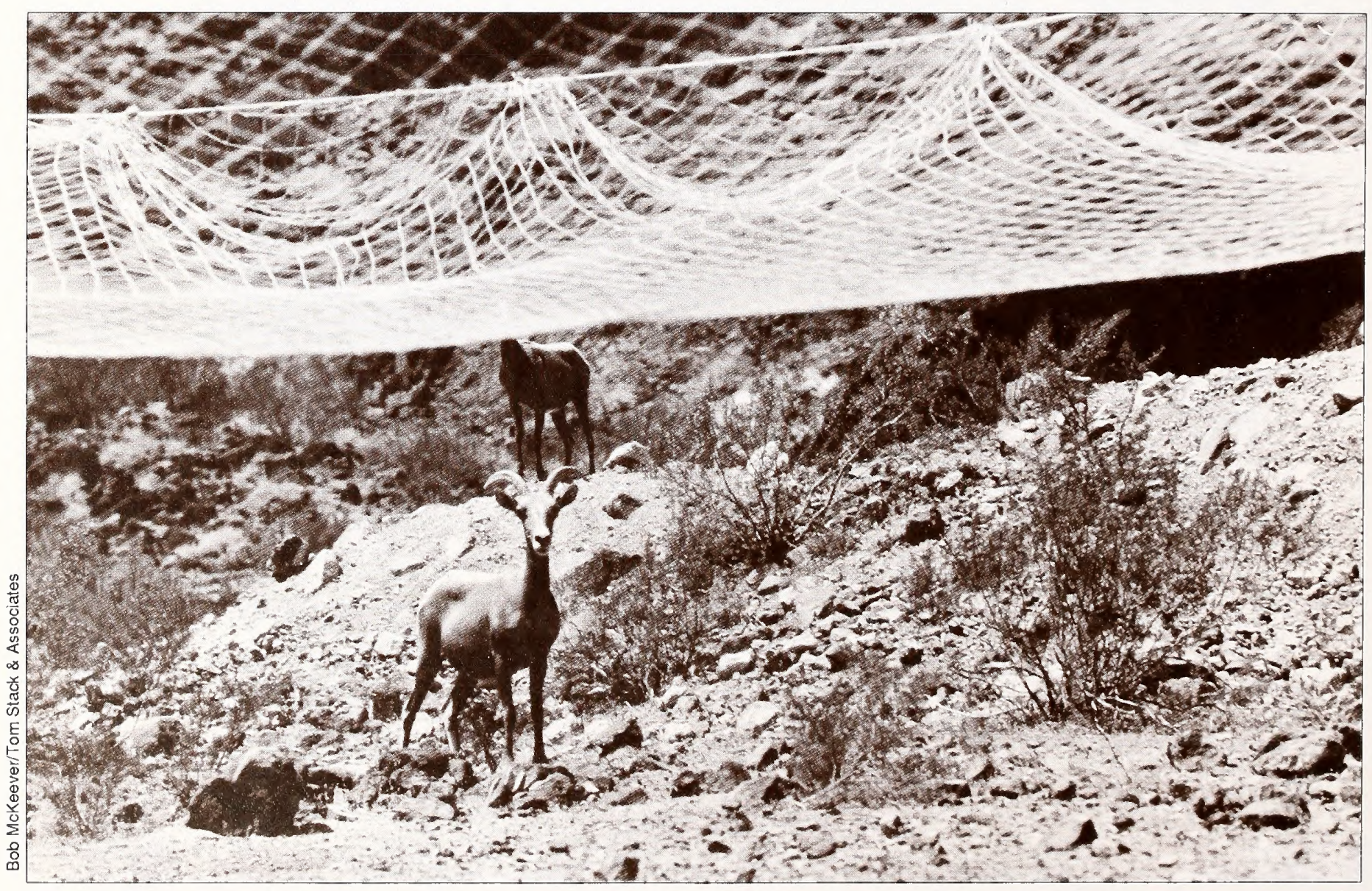

Desert Bighorns enter dropnet trap. 
State wildlife agencies for review and comment. Before preparing the final document, the authors of the plan met with representatives from each BLM State Office and each State wildlife agency to incorporate as many additional ideas or changes as possible. Following these revisions, the plan was sent to various organizations having particular interest in desert bighom such as the Foundation of North American Wild Sheep and the Desert Bighorn Council. The final plan was sent to the Directors of each State wildlife agency and presented to the BLM State Directors. Their comments and concerns have been incorporated into this printed draft. 



\section{The Plan}

The plan is presented in three sections. In Section 1, the overall goal and general objectives of the plan are described. Achievement of the goal and objectives will be the measure of the success of the program. In Section 2, general management practices and standards are described. Management practices are the means by which habitat can be maintained or enhanced to support viable populations of desert bighorn sheep. This section provides a synopsis of the known practices that the BLM will adhere to, when supporting a viable population of bighorn sheep is a management objective. In Section 3 , information needs are described. This section describes practices (inventory, monitoring, studies, research) and standards that must be followed to obtain the information necessary to enhance desert bighorn recovery.

\section{Section 1. Goal and Objectives}

The goal of the program is to facilitate the recovery of desert bighorn sheep in 115 identified habitat areas so that they can support viable populations of bighorn sheep. This goal will be achieved through the attainment of the following three objectives:

- Maintain or enhance the habitat of 33 habitat areas (Table 2) currently supporting viable populations of desert bighorn sheep (Category I areas),

- Enhance habitat on 58 habitat areas (Table 3) with remnant herds that are capable of supporting viable populations (Category II areas),

- Maintain and enhance historic habitat in 24 habitat areas (Table 4) to allow reintroduction and reestablishment of viable populations (Category III areas).

These 115 habitat areas do not represent all areas that historically or currently had desert bighorn, but only those that meet certain criteria discussed below. The other areas will continue to be managed in accordance with BLM policies and regulations but will not receive priority for funding or management efforts under the procedures described in this plan.

These habitat areas, listed in Tables 2 through 4 ,

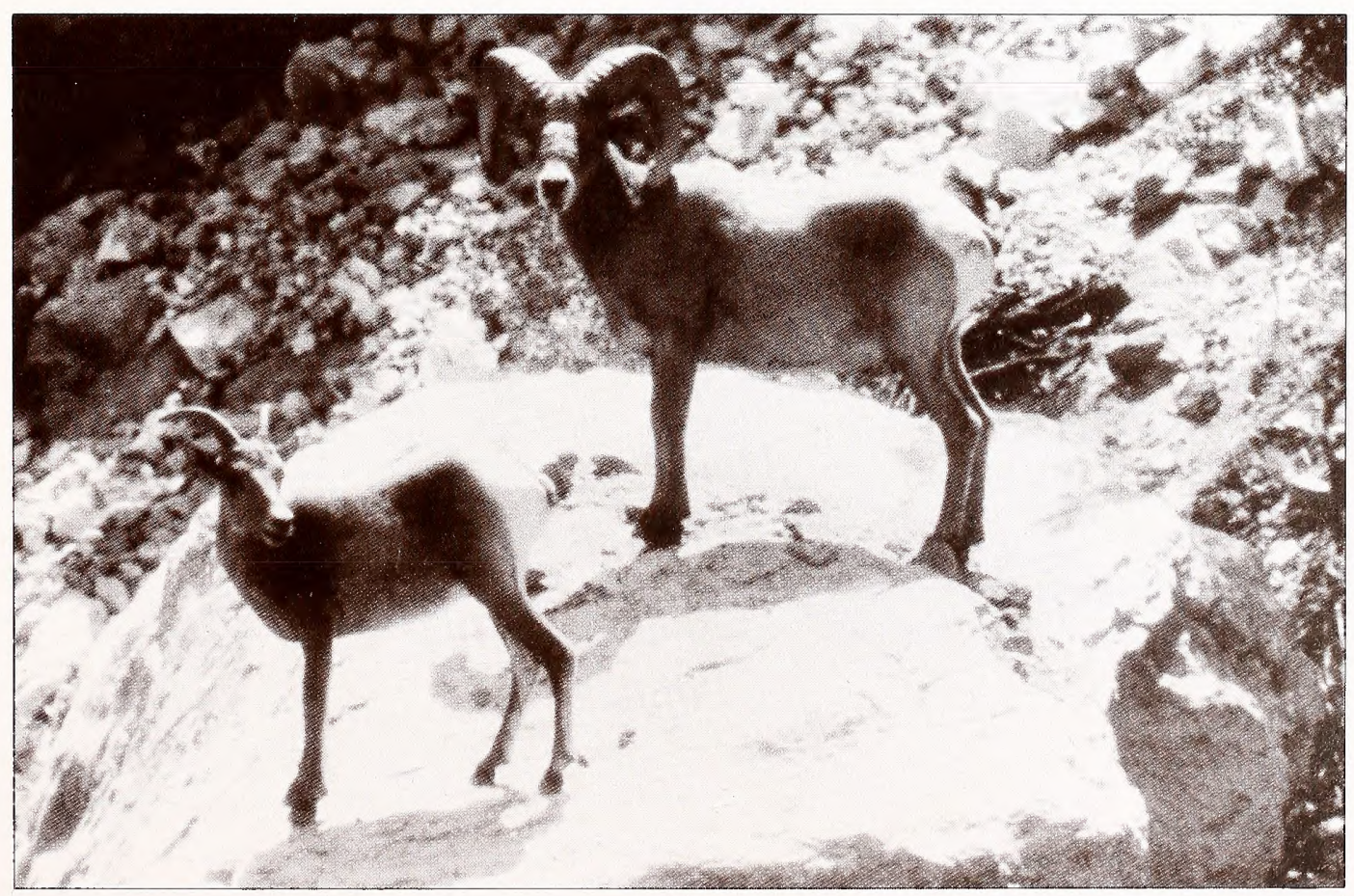

Peninsular Bighorn (Ovis canadensis cremnobates). 
Table 2. Habitat areas on BLM lands supporting viable populations of desert bighorn sheep (Category I Areas).

\begin{tabular}{|c|c|c|c|c|}
\hline Habitat Area & Subspecies & $\begin{array}{c}\text { Current } \\
\text { Population } \\
\text { Estimate }\end{array}$ & $\begin{array}{l}\text { Potential } \\
\text { Population } \\
\text { Estimate }\end{array}$ & $\begin{array}{c}\text { Percent } \\
\text { BLM }\end{array}$ \\
\hline \multicolumn{5}{|l|}{ Arizona } \\
\hline Aravaipa Canyon & Mexican & 160 & 300 & 90 \\
\hline Bill Williams Mountains/Aubrey Hills/Castenada Peak/ & Nelson & 100 & 160 & 85 \\
\hline Black Mountains & Nelson & 1200 & 1500 & 84 \\
\hline Eagletail/Little Hom/New Water/Paloma Mountains/Ridge/ & & & & \\
\hline Tank Mountains/Gila Bend Mountain Cemetary & Mexican & 290 & 400 & 98 \\
\hline Plomosa & Mexican & 194 & 250 & 98 \\
\hline Sand Tanks/Tabletop/Sauceda/Betamote/Coffee Pot Mountains & Mexican & 160 & 350 & 99 \\
\hline Trigo/Trigo Mountains/Chocolate/Dome Rock Mountains & Mexican & 200 & 240 & 50 \\
\hline Virgin Mountains & Nelson & 100 & 150 & 99 \\
\hline \multicolumn{5}{|l|}{ California } \\
\hline Clark Mountain & Nelson & 150 & 150 & 97 \\
\hline Kelso Mountains/Old Dad Peak & Nelson & 250 & 250 & 95 \\
\hline Kingston Mountains & Nelson & 150 & 180 & 97 \\
\hline Last Chance Range/Dry Mountain & Nelson & 100 & 150 & 85 \\
\hline Marble Mountains & Nelson & 180 & 200 & 55 \\
\hline New York/Providence/Woods Mountain/Hackberry Mountains & Nelson & 165 & 165 & 80 \\
\hline Picacho Peaks & Nelson & 110 & 150 & 55 \\
\hline Santa Rosa Mountains & Peninsular & 350 & 500 & 35 \\
\hline Turtle Mountains & Nelson & 110 & 150 & 96 \\
\hline \multicolumn{5}{|l|}{ Nevada } \\
\hline Arrow Canyon & Nelson & 117 & 396 & 99 \\
\hline Eldorado Mountains & Nelson & 424 & 742 & 50 \\
\hline Lone Mountain/Silver Peak/Monte Crisco & Nelson & 394 & 394 & unk \\
\hline Meadow Valley Mountains & Nelson & 175 & 510 & 100 \\
\hline Mormon Mountains & Nelson & 362 & 362 & 100 \\
\hline Muddy Mountains & Nelson & 265 & 505 & 88 \\
\hline Newberry & Nelson & 105 & 169 & 30 \\
\hline River Mountains & Nelson & 207 & 207 & 30 \\
\hline Stillwater Mtns. & Nelson & 102 & 350 & 99 \\
\hline \multicolumn{5}{|l|}{ New Mexico } \\
\hline Big Hatchet/Alamo Hueco/Little Hatchet & Mexican & 100 & 400 & 63 \\
\hline \multicolumn{5}{|l|}{ Utah } \\
\hline Kaparowitz Plateau & Nelson & 100 & 150 & 70 \\
\hline North San Juan & Nelson & 556 & 556 & 50 \\
\hline North San Rafael Desert & Nelson & 225 & 225 & 89 \\
\hline Potash & Nelson & 222 & 222 & 88 \\
\hline South San Juan & Nelson & 834 & 834 & 60 \\
\hline South San Rafael Desert & Nelson & 120 & 150 & 90 \\
\hline
\end{tabular}


Table 3. Habitat areas on BLM land with remnant herds that are capable of supporting viable populations (Category II Areas).

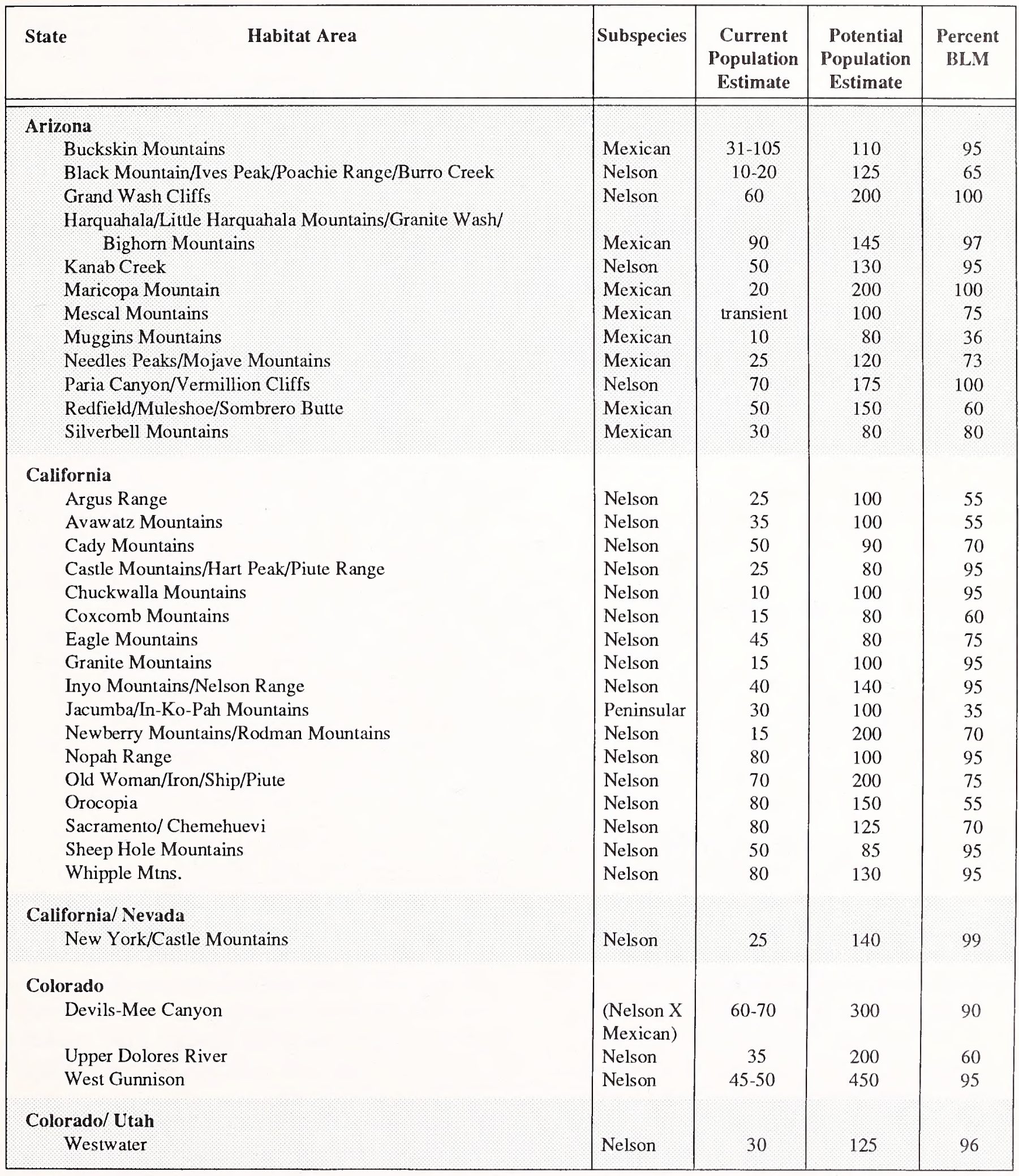


Table 3 (continued). Habitat areas on BLM land with remnant herds that are capable of supporting viable populations (Category II Areas).

\begin{tabular}{|c|c|c|c|c|}
\hline Habitat Area & Subspecies & $\begin{array}{c}\text { Current } \\
\text { Population } \\
\text { Estimate }\end{array}$ & $\begin{array}{c}\text { Potential } \\
\text { Population } \\
\text { Estimate }\end{array}$ & $\begin{array}{c}\text { Percent } \\
\text { BLM }\end{array}$ \\
\hline \multicolumn{5}{|l|}{ Nevada } \\
\hline Clan Alpine & Nelson & 30 & 125 & 99 \\
\hline Could Butte & Nelson & 20 & 671 & 99 \\
\hline Delmar Mountains & Nelson & 50 & 759 & 99 \\
\hline East Range & Nelson & 50 & unk & 68 \\
\hline Far South Egan Range & Nelson & 19 & unk & 99 \\
\hline Golden Gate Range & Nelson & transient & unk & 99 \\
\hline Highland & Nelson & 41 & 134 & 100 \\
\hline McCullough Mountains & Nelson & 80 & 734 & 99 \\
\hline Pahranagats & Nelson & unk & 574 & 99 \\
\hline South Pahroc & Nelson & 33 & 165 & 100 \\
\hline South Spring/Bird Spring Mountains & Nelson & 50 & 708 & 97 \\
\hline Tobin Range & Nelson & 44 & 339 & 97 \\
\hline Virgin Mountains & Nelson & 69 & 484 & 99 \\
\hline Worthington Mountains & Nelson & 25 & unk & 95 \\
\hline \multicolumn{5}{|l|}{ New Mexico } \\
\hline Peloncillo Mountains & Mexican & 30 & 400 & 50 \\
\hline \multicolumn{5}{|l|}{ Utah } \\
\hline Beckwith Plateau & Nelson & 39 & 200 & 90 \\
\hline Colorado River/Professor Valley & Nelson & 10 & 125 & 96 \\
\hline Dirty Devil & Nelson & $25-50$ & unk & unk \\
\hline Dolores River & Nelson & unk & 250 & 96 \\
\hline Horseshoe Canyon/Bowknot Bend & Nelson & 25 & 200 & 98 \\
\hline Kane Springs-Lockhart & Nelson & 50 & unk & 96 \\
\hline Little Rockies & Nelson & unk & unk & 96 \\
\hline San Juan River & Nelson & 72 & unk & 85 \\
\hline Westwater Canyon & Nelson & 30 & 125 & 96 \\
\hline
\end{tabular}

were given priority in the program based on data and feedback from BLM field biologists. These biologists recommend that the BLM give priority for funding and management to. .

- areas capable of supporting viable populations of desert bighorn sheep;

- areas where BLM, or BLM with other agencies or organizations, has both substantial management responsibility and also substantial control over activities on the land; and

- areas where conflicting land-uses will not prevent achievement of desert bighorn sheep objectives.
All 115 areas listed in Tables 2 through 4 meet these criteria.

In addition, the biologists identified two criteria for ranking priorities among these areas:

- Areas with the rarer subspecies (Peninsular bighorn, O.c. cremnobates and Mexican bighorn O.c. mexicana) should receive priority over the more common Nelson bighorn (O.c. nelsoni), and

- State wildlife agency priorities for habitat enhancement should receive a high priority.

These latter criteria will be used to determine annual funding priorities among the 115 habitat areas listed in Tables 2 through 4. 
Table 4. Historic desert bighorn habitat areas on BLM lands capable of supporting viable populations (Category III Areas).

\begin{tabular}{|c|c|c|c|c|}
\hline Habitat Area & Subspecies & $\begin{array}{l}\text { Current } \\
\text { Population } \\
\text { Estimate }\end{array}$ & $\begin{array}{l}\text { Potential } \\
\text { Population } \\
\text { Estimate }\end{array}$ & $\begin{array}{c}\text { Percent } \\
\text { BLM }\end{array}$ \\
\hline $\begin{array}{l}\text { Arizona } \\
\text { Gila Box }\end{array}$ & Nelson & 0 & 200 & 82 \\
\hline $\begin{array}{l}\text { Colorado } \\
\text { Lower Dolores River } \\
\text { Palisades }\end{array}$ & $\begin{array}{l}\text { Nelson } \\
\text { Nelson }\end{array}$ & $\begin{array}{l}0 \\
0\end{array}$ & $\begin{array}{l}400 \\
100\end{array}$ & $\begin{array}{r}99 \\
100\end{array}$ \\
\hline $\begin{array}{l}\text { Nevada } \\
\text { Bare Mountain }\end{array}$ & $\begin{array}{l}\text { Nelson } \\
\text { Nelson } \\
\text { Nelson } \\
\text { Nelson } \\
\text { Nelson } \\
\text { Nelson } \\
\text { Nelson } \\
\text { Nelson } \\
\text { Nelson } \\
\text { Nelson } \\
\text { Nelson } \\
\text { Nelson } \\
\text { Nelson } \\
\text { Nelson }\end{array}$ & $\begin{array}{l}0 \\
0 \\
0 \\
0 \\
0 \\
0 \\
0 \\
0 \\
0 \\
0 \\
0 \\
0 \\
0 \\
0\end{array}$ & $\begin{array}{l}169 \\
\text { unk } \\
360 \\
117 \\
359 \\
\text { unk } \\
\text { unk } \\
\text { unk } \\
218 \\
110 \\
240 \\
285 \\
\text { unk } \\
125\end{array}$ & $\begin{array}{r}50 \\
99 \\
99 \\
100 \\
76 \\
99 \\
99 \\
95 \\
99 \\
100 \\
90 \\
52 \\
\text { unk } \\
95\end{array}$ \\
\hline $\begin{array}{l}\text { Nevada/ Utah } \\
\text { Pilot Range }\end{array}$ & Nelson & 0 & 140 & 50 \\
\hline $\begin{array}{l}\text { New Mexico } \\
\text { Ladron Mountains }\end{array}$ & Mexican & 0 & 130 & 56 \\
\hline $\begin{array}{l}\text { Utah } \\
\text { Wah Wah Mountains } \\
\text { Newfoundland Mountains } \\
\text { Confusion Mountains } \\
\text { House Range Mountains } \\
\text { Red Mountain }\end{array}$ & $\begin{array}{l}\text { Nelson } \\
\text { Nelson } \\
\text { Nelson } \\
\text { Nelson } \\
\text { Nelson }\end{array}$ & $\begin{array}{l}0 \\
0 \\
0 \\
0 \\
0\end{array}$ & $\begin{array}{l}\text { unk } \\
500 \\
\text { unk } \\
\text { unk } \\
100\end{array}$ & $\begin{array}{l}94 \\
84 \\
92 \\
89 \\
95\end{array}$ \\
\hline
\end{tabular}

The interim measures identified for judging if areas have met these standards are described below.

A viable population has been defined as "one that is self-sustaining with minimal demographic or genetic intervention over the long term" (Wilcox 1986). The following types of information provide evidence that a given habitat area is capable of supporting a viable population:

- historic presence of viable populations (where the cause of the decline to non-viable levels was either non-habitat-related or, if habitat related, has been remedied);

- current presence of viable populations;
- large areas of suitable habitat; or

- carrying-capacity calculations that indicate the habitat would support a viable population (based on forage supply within suitable habitat or on an accepted habitat evaluation procedure).

To use such evidence quantitatively, however, one must estimate a number to represent a viable population of desert bighorn.

For this plan, a bighom herd of approximately 100 sheep $(100 \pm 20 \%)$ with normal sex and age structure will be considered a viable population. This number is consistent with opinions of bighorn sheep biologists (Geist 1975; Weaver 1986) and is 


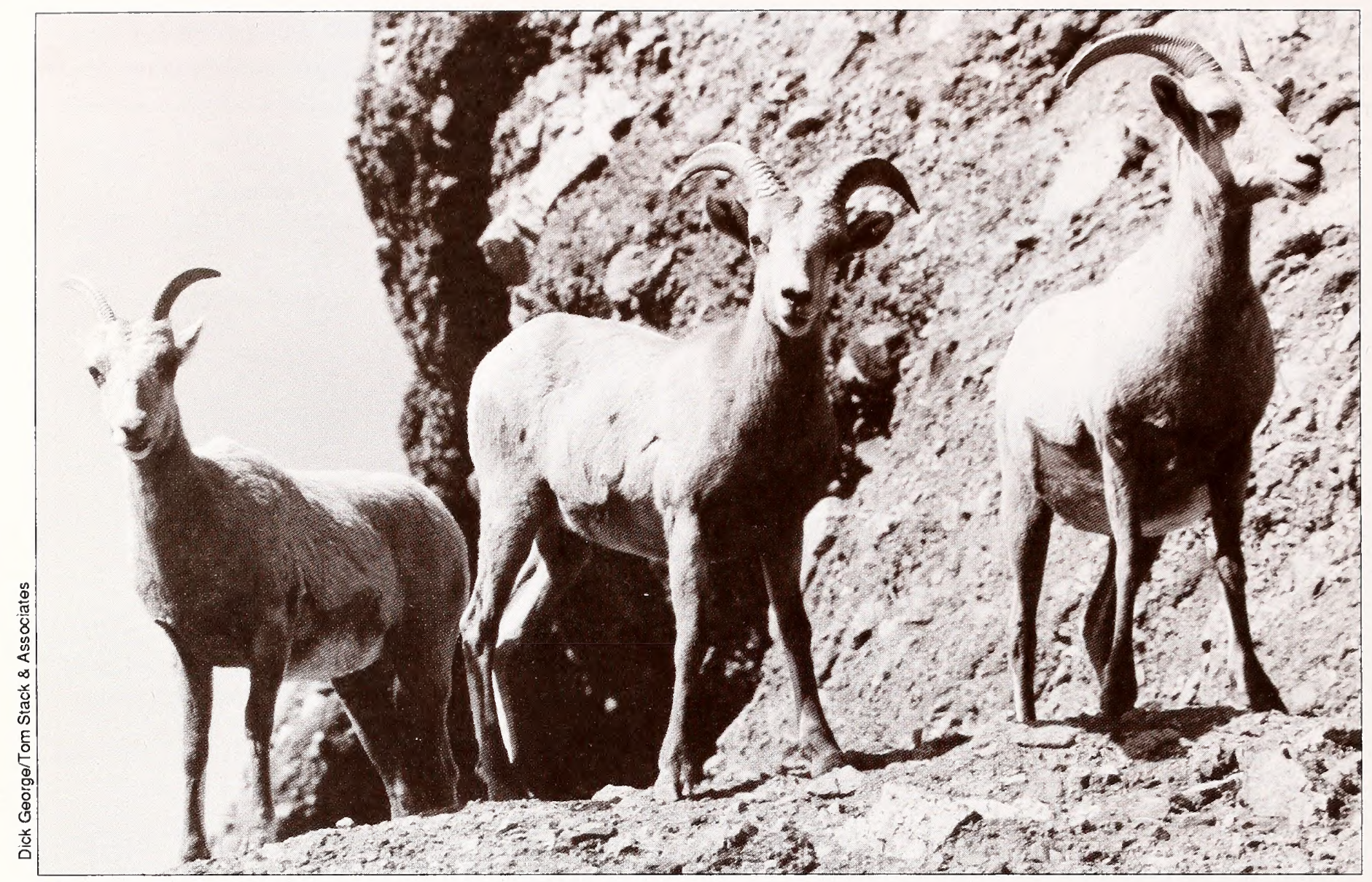

Mexican bighorn (Ovis canadensis mexicana).

supported by current evidence from conservation biology (Brussard 1986; Marcot et al. 1986). Thus, evidence that the habitat is capable of supporting a population of at least 100 sheep will be the general measure. Where acreage of suitable habitat is the only data available, 32,000 acres of bighorn habitat will be considered the smallest habitat size (based on two sheep per section [one sheep per 320 acres] on marginal bighorn range).

These guidelines do not disregard the potential importance of small semi-isolated populations. Rather the approach recognizes that small semiisolated populations need to be managed as part of an entire system or "metapopulation," as advocated by Krausman and Leopold (1985) and Schwartz et al. (1986). Where such situations exist, the criteria of $100 \pm 20$ animals is applied to the metapopulation.

This number is only a guideline to be used in identifying priorities for BLM funding and management. It is not intended to be used inflexibly, nor does the BLM claim that it represents a scientifically derived number or an absolute management criteria. The concept here is to concentrate funding and management effort where it will do the most long- term good. Biological and economic common sense demand that the BLM focus funding on habitats that can support self-sustaining populations. If future studies or research provide evidence that the BLM should be using a lower or higher number, this guideline will be adjusted accordingly.

Habitat areas that consist of at least 50 percent BLM lands are considered to be areas in which BLM has both substantial management responsibility and substantial control over other land-use activities. However, such a criteria has not and will not be used inflexibly, since local situations often are more important than arbitrary numbers. In particular, where other government agencies or private institutions together with BLM comprise over 50 percent of the habitat area, BLM may have substantial responsibility and control, particularly if the other organizations are committed to managing habitat for desert bighorn. Habitat areas comprising less than 30 percent BLM lands are not considered to be areas over which BLM has substantial control or responsibility. Although BLM might cooperate with another agency on desert bighorn habitat management on such areas, BLM would not normally have lead 
responsibility, and such areas are not considered priority areas for BLM's desert bighorn sheep program. The BLM should concentrate funding and management effort where other potentially detrimental activities can be controlled.

Habitat areas free of conflicting land-use activities are identified through the BLM's land-use planning process. As explained earlier, habitat areas to be managed for the purpose of supporting viable populations of desert bighorn sheep are identified in RMPs as are the general actions and allocations necessary to resolve conflicting land-use activities. The specific actions necessary to accomplish such objectives are identified in HMPs or other activity plans. The desert bighorn habitat areas identified in Tables 2 through 4 as priority areas are either (1) areas already identified in land-use plans to be managed for viable populations of desert bighorn sheep; or (2) areas tentatively identified as likely to be managed for such objectives following the next round of land-use planning. If the objectives for an area are changed during future land-use planning, the area will be added or deleted from the list of priority areas, as appropriate.
Subsequent research, studies, habitat inventories, monitoring and/or land-use planning may identify new areas that meet the three critical criteria (capability of supporting viable population; substantial BLM control; no land-use conflicts). These areas will be added to the list of priority areas. Similarly, future information and land-use decisions may identify areas for which managing to support viable populations of desert bighorn is no longer feasible or desirable. These areas will be dropped from the plan.

\section{Section 2. Management Practices and Standards}

Maintenance and restoration of desert bighom habitat require appropriate land-use management in addition to project work, such as water developments. The following practices and standards represent the best available knowledge on managing habitat to sustain viable populations of desert bighorn sheep.

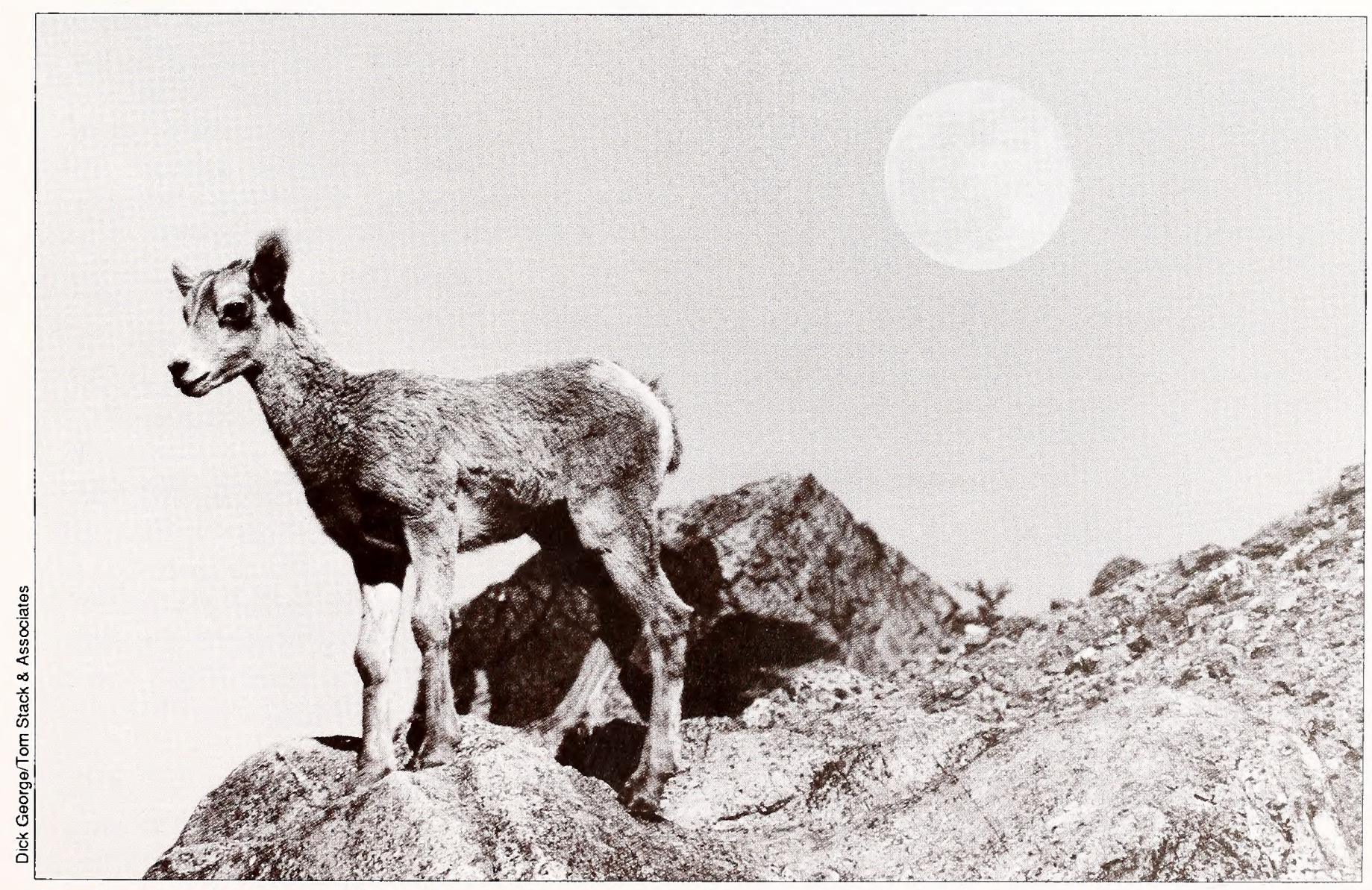

Lambing areas are crucial for desert bighorn survival. 
1. Crucial areas, such as lambing grounds, migration routes, mineral licks, and areas within 1 mile of permanent water sources, will receive maximum habitat protection.

2. Carrying-capacity determinations and forage allocations for desert bighom sheep, where necessary, will be based on a requirement of 4 pounds (air dry weight) of good quality bighorn forage per day.

3. To the extent possible, and with close coor-

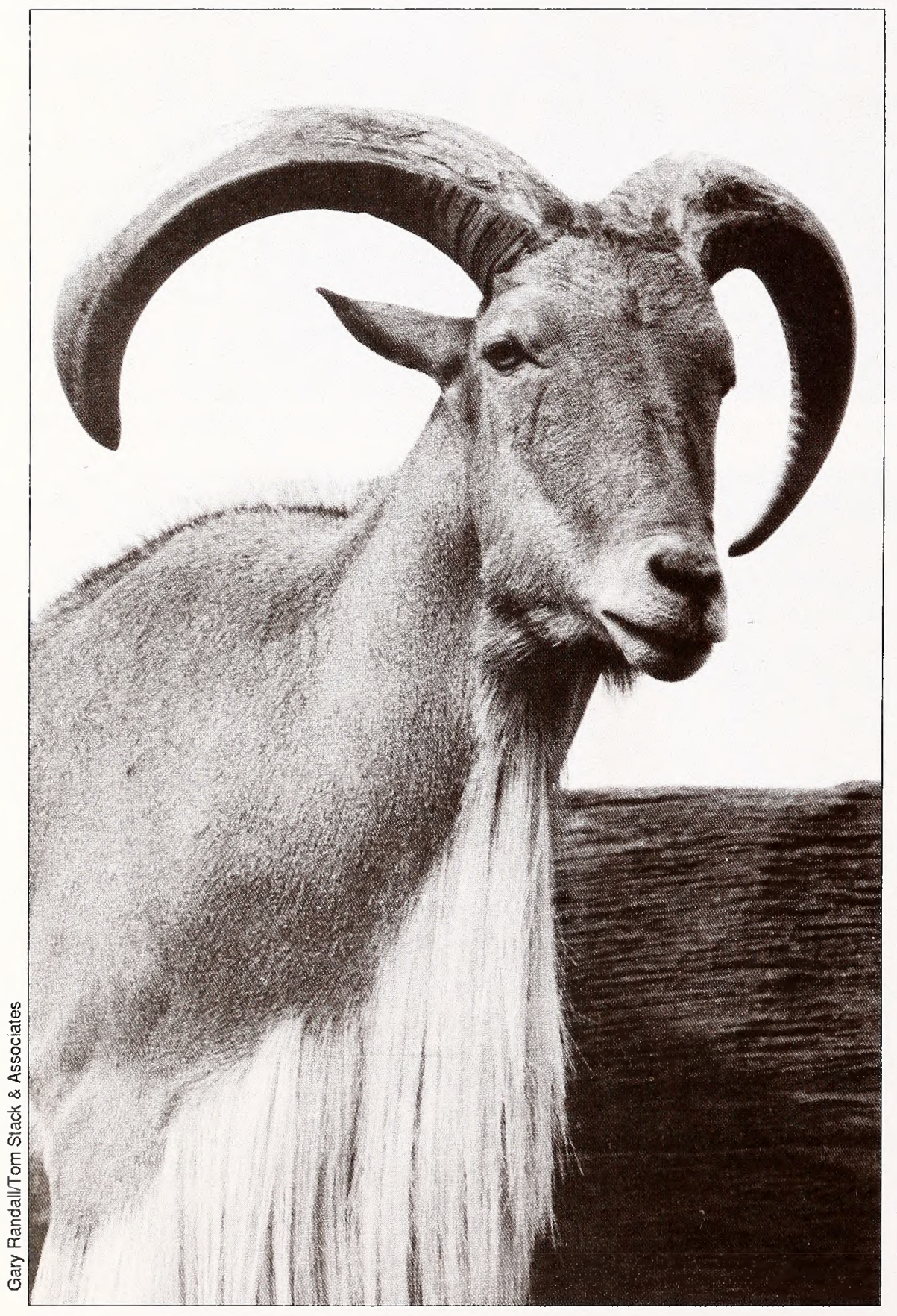

Barbary sheep, an introduced exotic, compete with desert bighorn for food and water. dination with State game departments, mule deer populations and habitat will be managed to minimize competition for food, water, cover, and space with desert bighorns.

4. Livestock grazing on desert bighorn habitats will be managed via land-use or activity plans to mitigate impacts to desert bighorn and their habitats and to ensure objectives for desert bighorn are being achieved.

5. Spread of junipers (Juniperus spp.), tamarix (Tamarix spp.), or other similar trees and shrubs into "open" habitats through plant succession, regression, or exotic plant introduction will be controlled to preserve open habitats.

6. Only 3-strand fences with the bottom wire smooth and the wires spaced 20, 35, and 39 inches from the ground will be constructed in desert bighorn habitat areas. Fencing of bighorn waters will be avoided except where necessary to reserve water for bighorn. All fencing will be according to BLM standards (U.S. Dep. Interior, Bureau of Land Management 1985).

7. If an exotic ungulate population occurs in a desert bighorn habitat, where the exotic species is capable of surviving and competing with desert bighorn, the population will be controlled at the lowest numbers possible. No new release of exotic ungulates will be permitted within desert bighorn habitats.

8. Wild horses and burros will be controlled at the lowest num- 


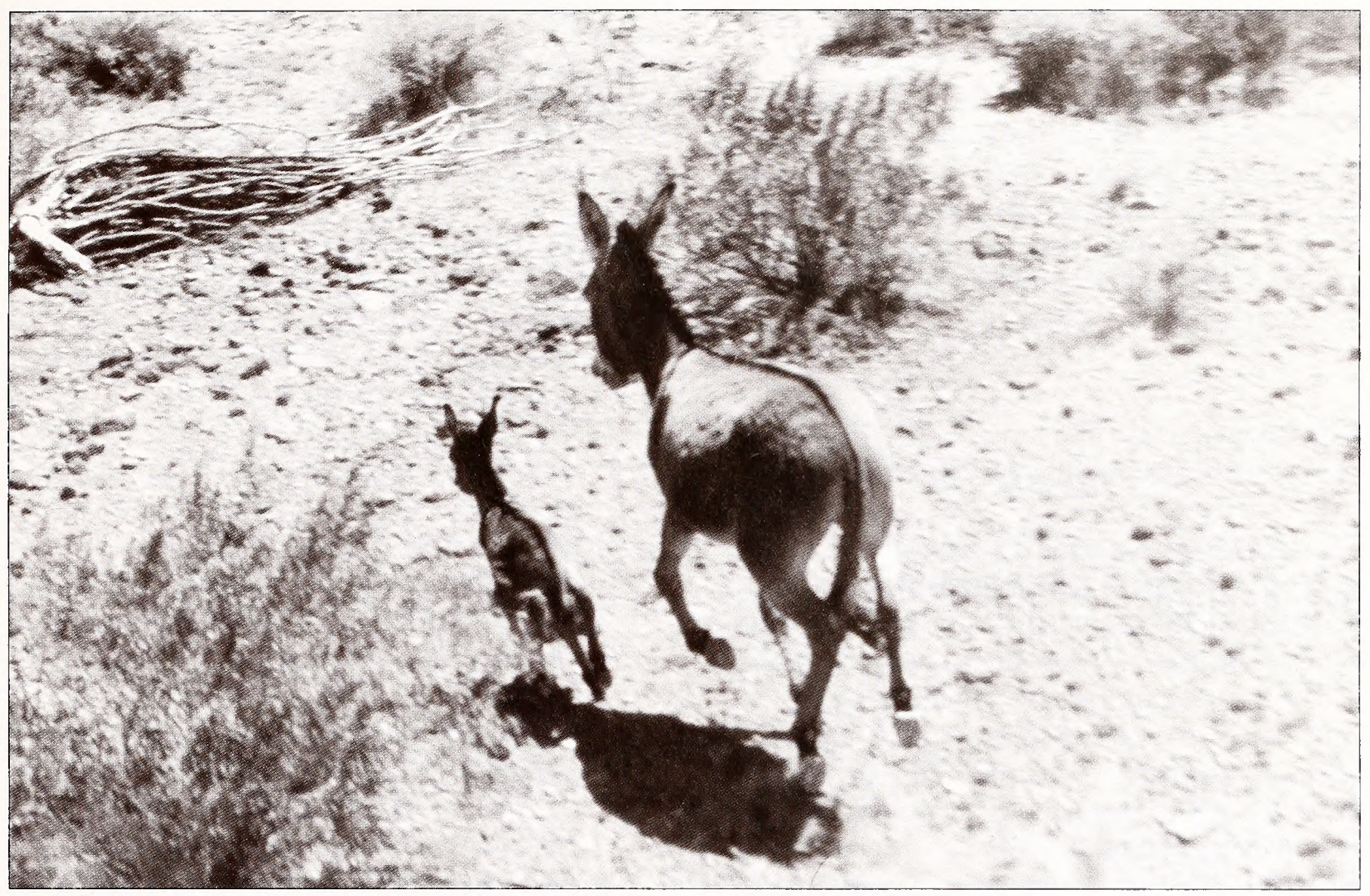

Feral Burros compete with desert bighorn for forage and other resources.

bers possible or as identified in land-use plans to mitigate impacts to desert bighorn and desert bighorn habitat.

9. Excessive use by recreationists will be regulated on major desert bighorn use areas.

10. To the extent possible, the BLM will not authorize activities that result in permanent human occupation or dwellings within desert bighorn habitat.

11. Off-road vehicles in desert bighorn habitats will be limited to existing roads and trails.

12. Impacts to desert bighorn or their habitats will be mitigated to the extent possible on all mineral or fossil fuel exploration and development proposals.

13. New road construction will be minimized in desert bighorn habitats and, where feasible, roads no longer serving a definite purpose will be "put to bed."
14. In carrying out BLM's responsibilities regarding reintroducing desert bighorn into historic habitats, BLM will be guided by established procedures as recommended by the Desert Bighorn Council (Wilson and Douglas 1982) and by newly accepted practices as they are developed.

15. For additional guidance on management of desert bighorn habitat, BLM will use established guidance as recommended by the Desert Bighorn Council (Wilson et al. 1980) or subsequent updates.

These recommended practices and standards are based on substantial literature and represent a consensus of biologists on the requirements to maintain viable populations of desert bighorn sheep. They will be used as guidelines in developing RMPs, HMPs, and other activity plans where BLM's objective is to maintain or restore habitat to support a viable desert bighorn sheep population. These guidelines will not be used to override management decisions already made through the land-use planning 
process. Where management objectives and practices are not consistent with these guidelines, funding will be redirected to areas where such conflicts do not exist until RMPs can be amended or management practices modified. BLM's commitment to following these practices and standards on areas where the objective is to maintain or restore habitat for viable populations will ensure efficient use of funds expended in the program.

\section{Section 3.}

\section{Information Needs and Standards}

A successful program for recovery of desert bighorn sheep requires good information. Standards and practices for obtaining information through inventory, monitoring, special studies, or research and development are described in this section.

Inventories of desert bighorn habitat and populations are needed to determine how to manage habitat for viable populations of desert bighorn. These inventories must be completed, documented, and used to develop desert bighorn management objectives in HMPs or other activity plans. Activity plans with desert bighorn objectives will be completed and approved according to BLM standards (U.S. Dep. Interior, Bureau of Land Management 1981).

Monitoring of desert bighorn populations and habitats is essential to determine if management objectives of activity plans are being achieved. Monitoring will be conducted on all areas being enhanced to support viable populations to see if objectives are being achieved.

Special studies are often necessary to obtain specific information such as bighorn seasonal movements or competition with other ungulates. Such studies will be conducted or contracted as information is needed for effective management and as funding is available.

Research and development is needed to solve habitat management problems and facilitate management. Research often takes many years to produce results that can be used by management. Thus, research and development represents an investment in the future and a long-term commitment. BLM will conduct or fund such efforts through a program of well-planned, adequately funded, goal-oriented research.
Specific research and development areas and topics have been identified and ranked by a task force of BLM biologists (U.S. Department of the Interior 1982). These topics fall into the following five general areas:

a. Disease andGenetics. Information is needed on the cause of both catastrophic and chronic mortality from disease, particularly lamb mortality, and the habitat factors that contribute to such mortality.

b. Nutritional Requirements. A method is needed to quantify carrying capacity of desert bighom ranges based on seasonal production and nutritional properties of forage in relation to nutritional requirements of the animal.

c. Impacts of Domestic Livestock and Feral Animals. The impact of varying densities of livestock or feral animals on desert bighorn and their habitat through competition for forage, space, and water and through transmission of disease needs to be understood.

d. Habitat Evaluation Techniques. An improved, standardized, and computer-compatible procedure for habitat evaluation is needed. This system would provide a standardized rating system for habitats presently occupied by bighorn as well as for those being considered for introductions.

e. Methodology for Mitigation and Habitat Improvement. A set of specific, practical, and uniform guidelines for mitigating impacts to desert bighom habitat or for habitat improvement is needed.

More specific discussion of these topics and proposed strategies for pursuing such information needs are found in the task force report (U.S. Department of the Interior 1982). This effort will be guided by this report and coordinated through the BLM Service Center. In order to achieve continuity in the research program, BLM will commit approximately 10 to 15 percent of the program funding to research and development annually. 
However, so that such efforts do not encroach upon ongoing management, the research and development effort will never exceed 15 percent of the total program for a given year. 



\section{Future Activities, Plan Revisions, and Monitoring}

Long-range plans incorporating vast areas must be dynamic if they are to continue to be useful as management guidelines. Therefore, the previously stated goal, objectives, and procedures will be revised as necessary. Similarly, the management practices and information needs will be modified or amended as new information becomes available.
Information from inventory, monitoring, and research will provide the basis for formally updating the plan every 5 years. The number of habitat areas that are supporting viable populations, as reported by the field offices, will ultimately measure the success of the program. 



\section{Summary}

The BLM's desert bighom program will be continued under the direction of this management plan. Adherence to the plan should facilitate maintenance of 33 desert bighorn viable populations, recovery of an additional 58 populations to viable population size, and reintroduction of populations into 24 historic habitat areas. All of these objectives can be met within the next 10 years with adequate funding. 



\section{Literature Cited}

BRUSSARD, P.F. 1986. The Perils of Small Populations II: Genetic Threats to Persistence. Chapter 4, pp. 33-40 in Wilcox, B.A., P.F. Brussard, and B.G. Marcot (Eds.) The Management of Viable Populations-Theory, Applications and Case Studies. Center for Conservation Biology, Stanford University, 188 pp.

BUECHNER, H.K. 1960. The bighorn sheep in the United States, its past, present, and future. Wildl. Monogr. No. 4, 174 pp.

COOPERRIDER, A.Y. 1985. The desert bighorn. Pages 472-485 in R.L. Di Silvestro, ed. Audubon Wildlife Report 1985, The National Audubon Society, New York, N.Y. 671 pp.

1986. BLM's desert bighorn sheep program. Trans. N. Amer. Wildlife and Natural Resources Conference 51:45-51.

GEIST, V. 1975. On the management of mountain sheep: theoretical considerations. Pages 77-105 in J.B. Trefethen, ed. The wild sheep in modern North America. Proc. of the Workshop on the Management Biology of North American Wild Sheep. Boone and Crockett Club, New York, N.Y. 302 pp.

KELLY, W.E. 1980. Hunting. Pages 336-342 in G. Monson and L. Sumner, eds. The desert bighomits life history, ecology, and management. Univ. Arizona Press, Tucson, 370 pp.

KRAUSMAN, P.R. and B.D. LEOPOLD. 1986. The importance of small populations of desert bighorn sheep. Trans. N. Amer. Wildl. and Nat. Res. Conf. 51:52-61.

MARCOT, B.G., R.S. Holthausen, and H. Salwasser. 1986. Viable population planning. Chapter 6, pp. 49-62 in Wilcox, B.A., P.F. Brussard, and B.G. Marcot (Eds.) The Management of Viable Populations-Theory, Applications and Case Studies. Center for Conservation Biology, Stanford University, $188 \mathrm{pp}$.
SCHWARTZ, O.A., V.C. Bleich, and S.A. Holl. 1986. Genetics and conservation of mountain sheep Ovis canadensis nelsoni. Biol. Conserv. 37:179190.

\section{U.S. DEPARTMENT OF THE INTERIOR, BUREAU OF LAND MANAGEMENT. 1981. Manual 6780 - Habitat Management Plans. Unnum- bered.}

\section{U.S. DEPARTMENT OF THE INTERIOR,} BUREAU OF LAND MANAGEMENT. 1982. Research needs for desert bighorn sheep habitat. Unpub. Report, 16 pp.

\section{U.S. DEPARTMENT OF THE INTERIOR, BUREAU OF LAND MANAGEMENT. 1985. Manual Handbook H-1741-1 - Fencing. Unnum- bered}

WEAVER, R.A. 1985. The status of the desert bighorn in the United States. pp. 82-85 in M. Hoefs (ed.) Wild Sheep-Distribution, abundance, management and conservation of the sheep of the world and closely related mountain ungulates. Northern Wild Sheep and Goat Council, Special Report, $218 \mathrm{pp}$.

WEAVER, R. 1986. Personal communication. Mr. Weaver indicated that all the desert bighorn ranges in the California Desert that were originally estimated to have less than 80 animals, no longer supported bighorn populations. The original estimates were made in late 1950s and early 1960s.

WILCOX, B.A. 1986. Introduction. Chapter 1, pp. 1-6 in Wilcox, B.A., P.F. Brussard, and B.G. Marcot (Eds.) The Management of Viable PopulationsTheory, Applications and Case Studies. Center for Conservation Biology, Stanford University, 188 pp.

WILSON, L.O. 1975. Report and recommendations of the desert and Mexican bighorn sheep workshop group. Pages 110-143 in J.B. Trefethen, ed. The Wild Sheep in Modern North America. Proc. of 
the Workshop on the Management Biology or North American Wild Sheep. Boone and Crockett Club, New York. 302 pp.

WILSON, L.O. and C.L. DOUGLAS (Eds.). 1982. Revised procedures for capturing and re-establishing desert bighorn. Trans. Desert Bighorn Council 26:1-7.
WILSON, L.O., J. Blaisdell, G. Welsh, R. Weaver, R. Brisham, W. Kelly, J. Yoakum, M. Hinks, J. Turner, and J. DeForge. 1980. Desert bighorn habitat requirements and management recommendations. Trans. Desert Bighorn Council 24:1-7. 


\section{Appendix}




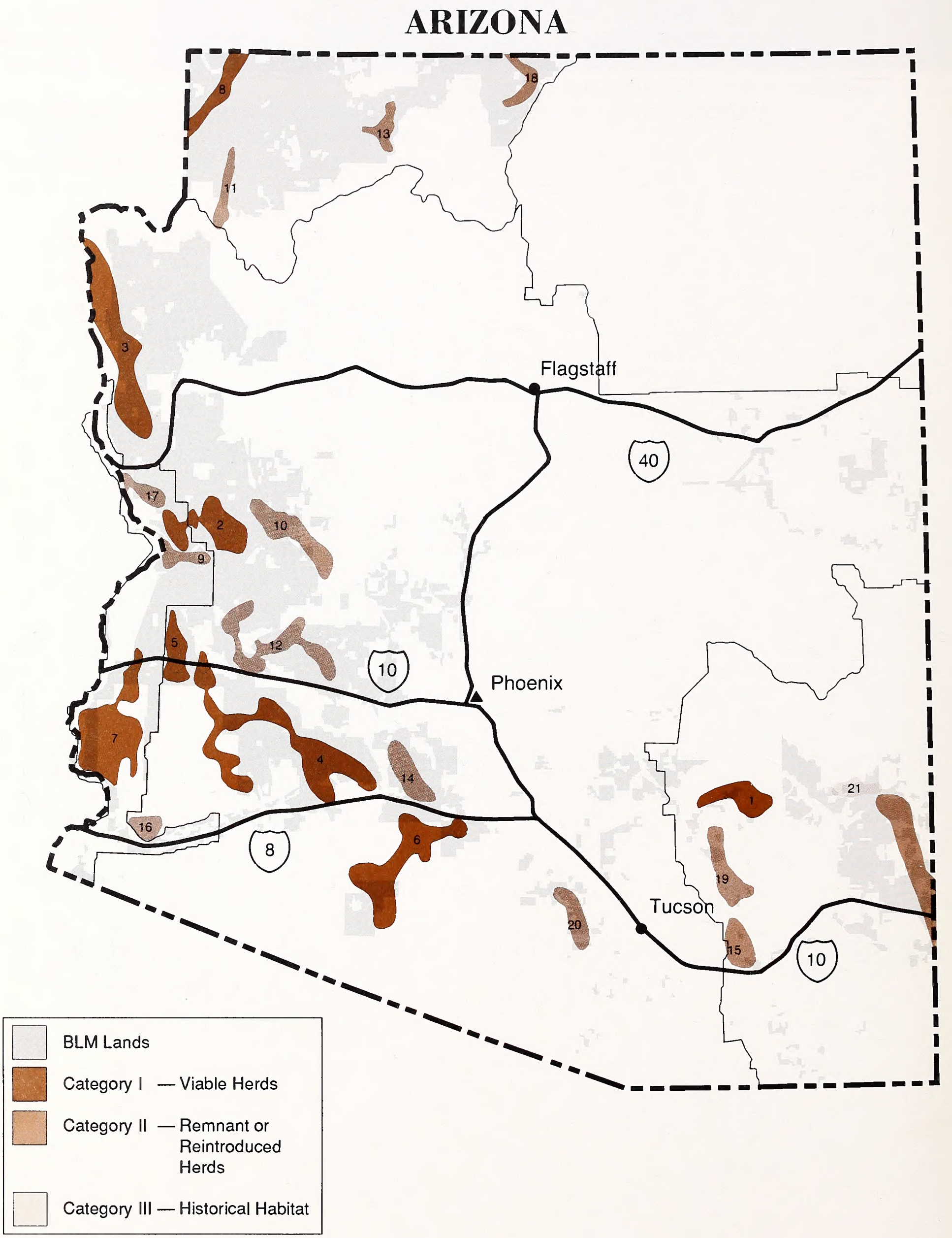




\begin{tabular}{|c|c|c|c|c|}
\hline $\begin{array}{c}\text { Arizona } \\
\text { Habitat Area }\end{array}$ & Subspecies & $\begin{array}{c}\text { Current } \\
\text { Population } \\
\text { Estimate }\end{array}$ & $\begin{array}{l}\text { Potential } \\
\text { Population } \\
\text { Estimate }\end{array}$ & $\begin{array}{l}\text { Percent } \\
\text { BLM }\end{array}$ \\
\hline \multicolumn{5}{|l|}{ Category I } \\
\hline $\begin{array}{l}\text { 1. Aravaipa Canyon } \\
\text { 2. Bill Williams Mountains/Aubrey Hills/ } \\
\text { Castenada Peak/Aubrey Peak } \\
\text { 3. Black Mountains } \\
\text { 4. Eagletail/Little Horn/New Water/ } \\
\text { Paloma Mountains/Cemetary Ridge/ } \\
\text { Tank Mountains/Gila Bend Mountain } \\
\text { 5. Plomosa } \\
\text { 6. Sand Tanks/Tabletop/Sauceda } \\
\text { Betamote/Coffee Pot Mountains } \\
\text { 7. Trigo/Trigo Mountains/Chocolate/ } \\
\text { 8. Dome Rock Mountains } \\
\text { Virgin Mountains }\end{array}$ & $\begin{array}{l}\text { Mexican } \\
\text { Mexican } \\
\text { Mexican } \\
\text { Mexican } \\
\text { Nelson }\end{array}$ & $\begin{array}{l}290 \\
194 \\
\\
160 \\
200 \\
100\end{array}$ & $\begin{array}{l}400 \\
250 \\
\\
350 \\
\\
240 \\
150\end{array}$ & $\begin{array}{l}98 \\
98 \\
\\
99 \\
\\
50 \\
99\end{array}$ \\
\hline \multicolumn{5}{|l|}{ Category II } \\
\hline $\begin{array}{l}\text { 9. Buckskin Mountains } \\
\text { 10. Black Mountain/lves Peak/ } \\
\text { 11. Gachie Range/Burro Creek } \\
\text { 12. Harquahala/Little Harquahala Mountains/ } \\
\text { Granite Wash/Bighorn Mountains } \\
\text { 13. Kanab Creek } \\
\text { 14. Maricopa Mountain } \\
\text { 15. Mescal Mountains } \\
\text { 16. Muggins Mountains } \\
\text { 17. Needles Peaks/Mojave Mountains } \\
\text { 18. Paria Canyon/Vermillion Cliff } \\
\text { 19. Redfield/Muleshoe/Sombrero Butte } \\
\text { 20. Silverbell Mountains }\end{array}$ & $\begin{array}{l}\text { Mexican } \\
\text { Nelson } \\
\text { Nelson } \\
\text { Mexican } \\
\text { Nelson } \\
\text { Mexican } \\
\text { Mexican } \\
\text { Mexican } \\
\text { Mexican } \\
\text { Nelson } \\
\text { Mexican } \\
\text { Mexican }\end{array}$ & $\begin{array}{c}31-105 \\
10-20 \\
60 \\
\\
90 \\
50 \\
20 \\
\text { transient } \\
10 \\
25 \\
70 \\
50 \\
30\end{array}$ & $\begin{array}{r}110 \\
125 \\
200 \\
\\
145 \\
130 \\
200 \\
100 \\
80 \\
120 \\
175 \\
150 \\
80\end{array}$ & $\begin{array}{r}95 \\
65 \\
65 \\
100 \\
\\
97 \\
95 \\
100 \\
75 \\
36 \\
73 \\
100 \\
60 \\
80\end{array}$ \\
\hline \multicolumn{5}{|l|}{ Category III } \\
\hline 21. Gila Box & Nelson & 0 & 200 & 82 \\
\hline
\end{tabular}




\section{CALIFORNIA}

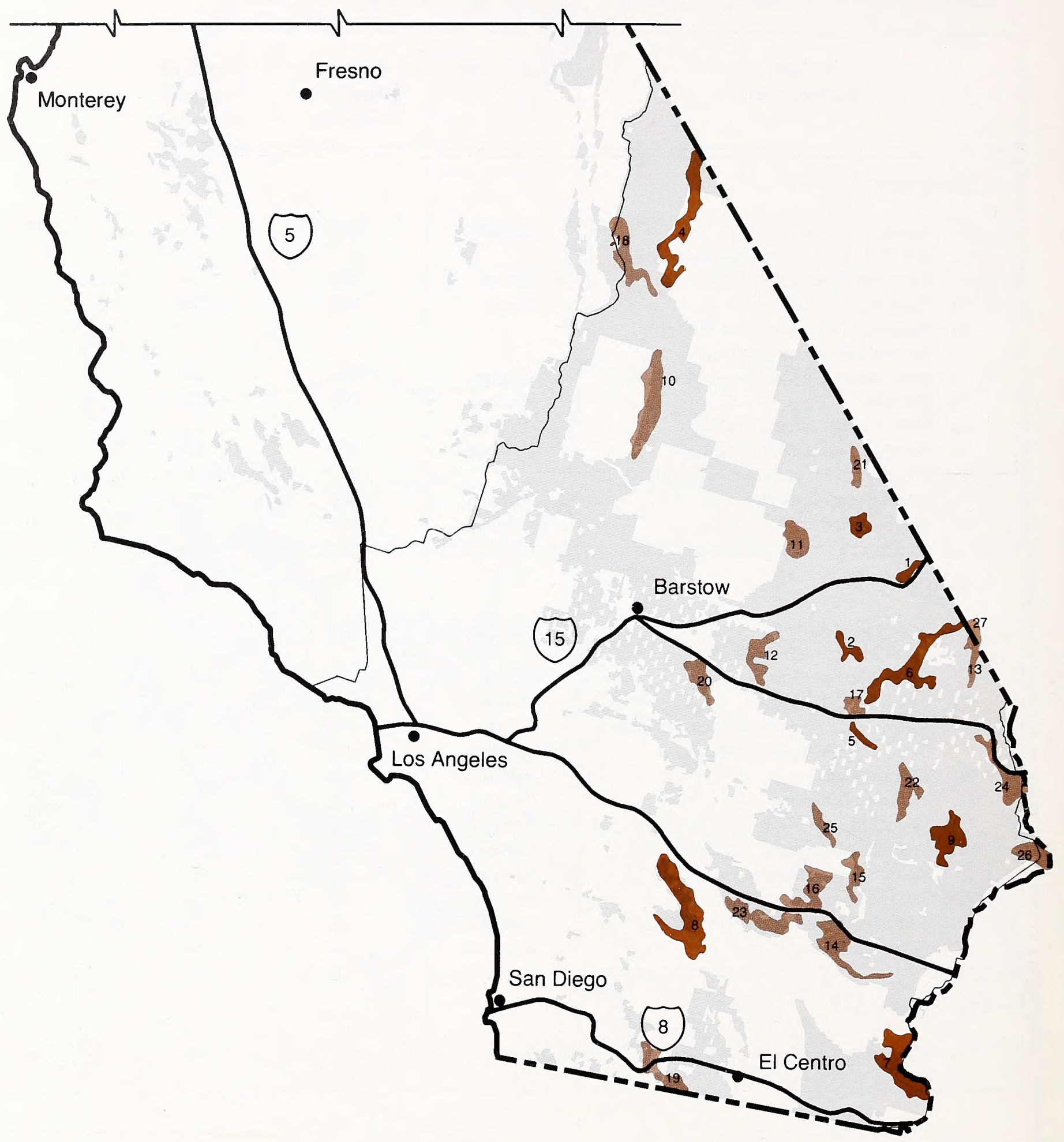

BLM Lands

Category 1 - Viable Herds

Category II - Remnant or Reintroduced Herds 


\begin{tabular}{|c|c|c|c|c|}
\hline $\begin{array}{l}\text { California } \\
\text { Habitat Area }\end{array}$ & Subspecies & $\begin{array}{l}\text { Current } \\
\text { Population } \\
\text { Estimate }\end{array}$ & $\begin{array}{l}\text { Potential } \\
\text { Population } \\
\text { Estimate }\end{array}$ & $\begin{array}{l}\text { Percent } \\
\text { BLM }\end{array}$ \\
\hline \multicolumn{5}{|l|}{ Category I } \\
\hline $\begin{array}{ll}\text { 1. } & \text { Clark Mountain } \\
\text { 2. Kelso Mountains/Old Dad Peak } \\
\text { 3. Kingston Mountains } \\
\text { 4. Last Chance Range/Dry Mountain } \\
\text { 5. Marble Mountains } \\
\text { 6. New York/Providence/Woods Mountain/ } \\
\text { Hackberry Mountains } \\
\text { 7. Picacho Peaks } \\
\text { 8. Santa Rosa Mountains } \\
\text { 9. Turtle Mountains }\end{array}$ & $\begin{array}{l}\text { Nelson } \\
\text { Nelson } \\
\text { Nelson } \\
\text { Nelson } \\
\text { Nelson } \\
\text { Nelson } \\
\text { Nelson } \\
\text { Peninsular } \\
\text { Nelson }\end{array}$ & $\begin{array}{l}150 \\
250 \\
150 \\
100 \\
180 \\
\\
165 \\
110 \\
350 \\
110\end{array}$ & $\begin{array}{l}150 \\
250 \\
180 \\
150 \\
200 \\
\\
165 \\
150 \\
500 \\
150\end{array}$ & $\begin{array}{l}97 \\
95 \\
97 \\
85 \\
55 \\
\\
80 \\
55 \\
35 \\
96\end{array}$ \\
\hline \multicolumn{5}{|l|}{ Category II } \\
\hline $\begin{array}{l}\text { 10. Argus Range } \\
\text { 11. Avawatz Mountains } \\
\text { 12. Cady Mountains } \\
\text { 13. Castle Mountains/Hart Peak/Piute Range } \\
\text { 14. Chuckwalla Mountains } \\
\text { 15. Coxcomb Mountains } \\
\text { 16. Eagle Mountains } \\
\text { 17. Granite Mountains } \\
\text { 18. Inyo Mountains/Nelson Range } \\
\text { 19. Jacumba/In-Ko-Pah Mountains } \\
\text { 20. Newberry Mountains/Rodman Mountains } \\
\text { 21. Nopah Range } \\
\text { 22. Old Woman Mountains } \\
\text { 23. Orocopia Mountains/Mecca Hills } \\
\text { 24. Sacramento Mountains/ } \\
\text { 25. Shemehuevi Mountains } \\
\text { 26. Whipple Mountains } \\
\text { 27. New York/Castle Mountains } \\
\text { (California/Nevada) }\end{array}$ & $\begin{array}{l}\text { Nelson } \\
\text { Nelson } \\
\text { Nelson } \\
\text { Nelson } \\
\text { Nelson } \\
\text { Nelson } \\
\text { Nelson } \\
\text { Nelson } \\
\text { Nelson } \\
\text { Peninsular } \\
\text { Nelson } \\
\text { Nelson } \\
\text { Nelson } \\
\text { Nelson } \\
\text { Nelson } \\
\text { Nelson } \\
\text { Nelson } \\
\text { Nelson }\end{array}$ & $\begin{array}{l}25 \\
35 \\
50 \\
25 \\
10 \\
15 \\
45 \\
15 \\
40 \\
30 \\
15 \\
80 \\
70 \\
80 \\
\\
80 \\
50 \\
80 \\
\\
25\end{array}$ & $\begin{array}{r}100 \\
100 \\
90 \\
80 \\
100 \\
80 \\
80 \\
100 \\
140 \\
100 \\
200 \\
100 \\
200 \\
150 \\
\\
125 \\
85 \\
130 \\
\\
140\end{array}$ & $\begin{array}{l}55 \\
55 \\
70 \\
95 \\
95 \\
60 \\
75 \\
95 \\
95 \\
35 \\
70 \\
95 \\
75 \\
55 \\
70 \\
95 \\
95 \\
99\end{array}$ \\
\hline
\end{tabular}




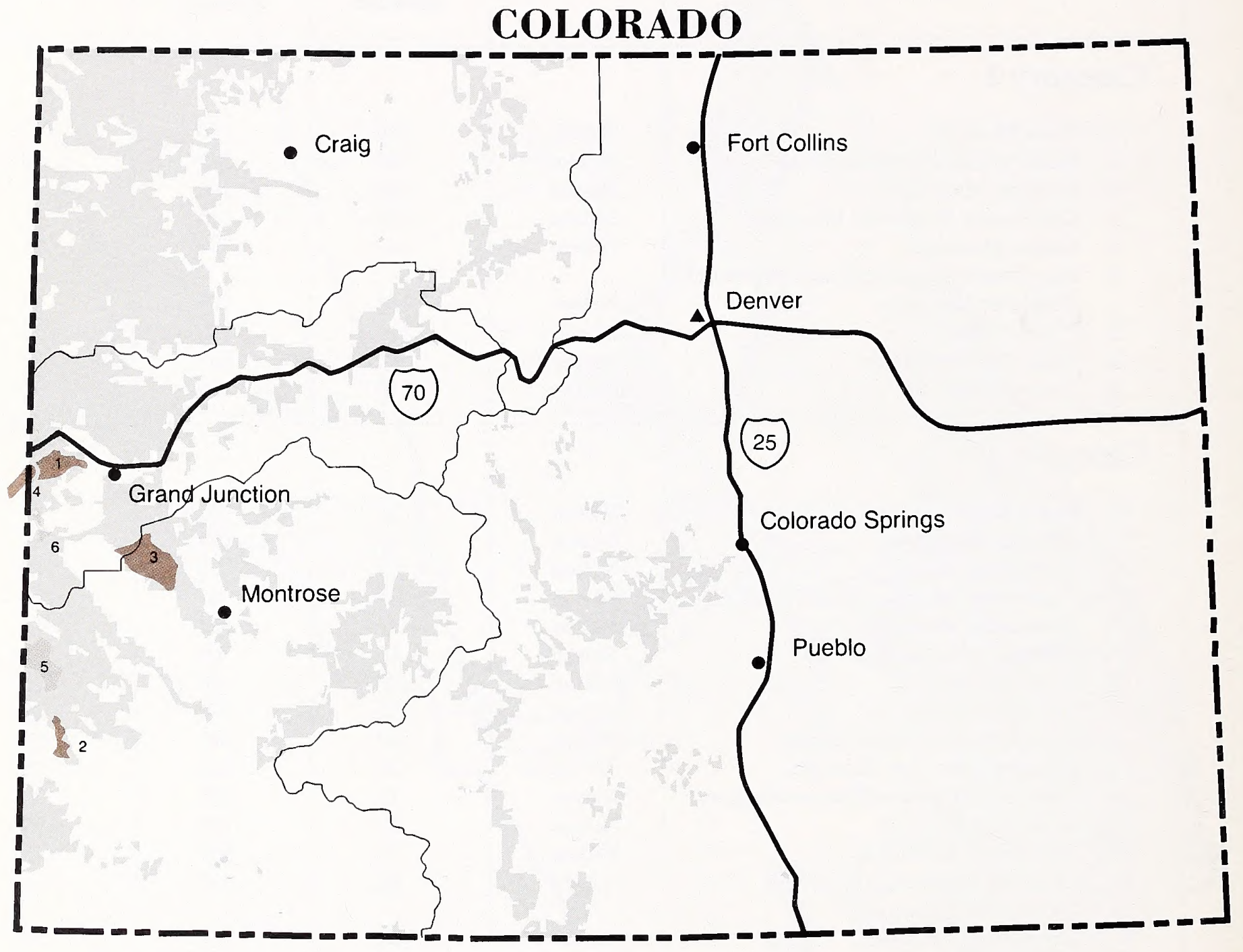

BLM Lands

Category II - Remnant or

Reintroduced Herds

Category III - Historical Habitat 


\begin{tabular}{|c|c|c|c|c|}
\hline $\begin{array}{c}\text { Colorado } \\
\text { Habitat Area }\end{array}$ & Subspecies & $\begin{array}{c}\text { Current } \\
\text { Population } \\
\text { Estimate }\end{array}$ & $\begin{array}{l}\text { Potential } \\
\text { Population } \\
\text { Estimate }\end{array}$ & $\begin{array}{l}\text { Percent } \\
\text { BLM }\end{array}$ \\
\hline \multicolumn{5}{|l|}{ Category II } \\
\hline $\begin{array}{l}\text { 1. Devils-Mee Canyon } \\
\text { 2. Upper Dolores River } \\
\text { 3. West Gunnison } \\
\text { 4. Westwater (Colorado/Utah) }\end{array}$ & $\begin{array}{l}\text { (Nelson X } \\
\text { Mexican) } \\
\text { Nelson } \\
\text { Nelson } \\
\text { Nelson }\end{array}$ & $\begin{array}{r}60-70 \\
35 \\
45-50 \\
30\end{array}$ & $\begin{array}{l}300 \\
200 \\
450 \\
125\end{array}$ & $\begin{array}{l}90 \\
60 \\
95 \\
96\end{array}$ \\
\hline \multicolumn{5}{|l|}{ Category III } \\
\hline $\begin{array}{l}\text { 5. Lower Dolores River } \\
\text { 6. Palisades }\end{array}$ & $\begin{array}{l}\text { Nelson } \\
\text { Nelson }\end{array}$ & $\begin{array}{l}0 \\
0\end{array}$ & $\begin{array}{l}400 \\
100\end{array}$ & $\begin{array}{r}99 \\
100\end{array}$ \\
\hline
\end{tabular}


NEVADA

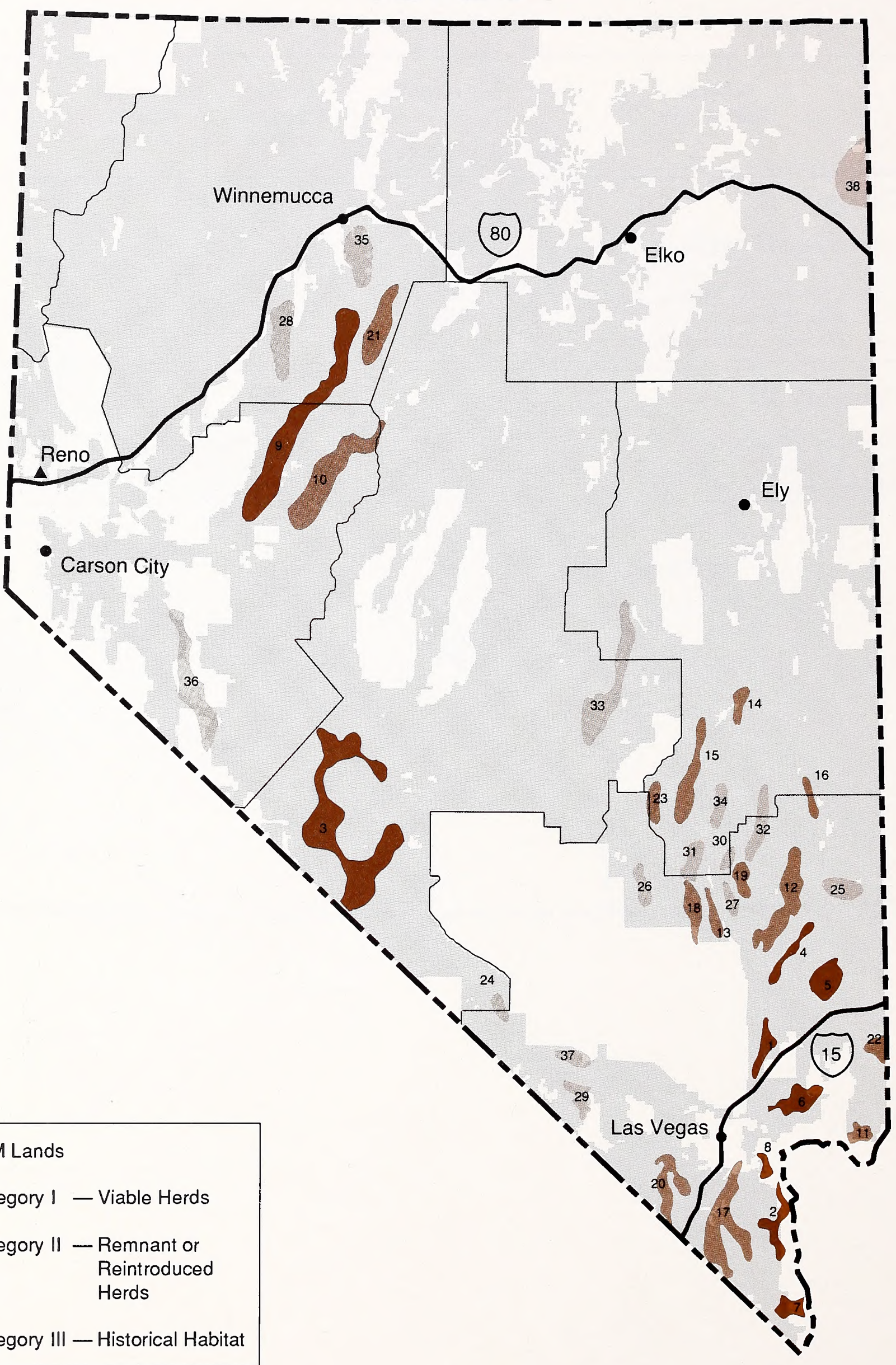




\begin{tabular}{|c|c|c|c|c|}
\hline $\begin{array}{c}\text { Nevada } \\
\text { Habitat Area }\end{array}$ & Subspecies & $\begin{array}{l}\text { Current } \\
\text { Population } \\
\text { Estimate }\end{array}$ & $\begin{array}{l}\text { Potential } \\
\text { Population } \\
\text { Estimate }\end{array}$ & $\begin{array}{c}\text { Percent } \\
\text { BLM }\end{array}$ \\
\hline \multicolumn{5}{|l|}{ Category I } \\
\hline $\begin{array}{l}\text { 1. Arrow Canyon } \\
\text { 2. Eldorado Mountains } \\
\text { 3. Lone Mountain/Silver Peak/ } \\
\text { 4onte Crisco } \\
\text { 4. Meadow Valley Mountains } \\
\text { 5. Mormon Mountains } \\
\text { 6. Muddy Mountains } \\
\text { 7. Newberry } \\
\text { 8. River Mountains } \\
\text { 9. Stillwater Mountains }\end{array}$ & $\begin{array}{l}\text { Nelson } \\
\text { Nelson } \\
\text { Nelson } \\
\text { Nelson } \\
\text { Nelson } \\
\text { Nelson } \\
\text { Nelson } \\
\text { Nelson } \\
\text { Nelson }\end{array}$ & $\begin{array}{l}117 \\
424 \\
\\
394 \\
175 \\
362 \\
265 \\
105 \\
207 \\
102\end{array}$ & $\begin{array}{r}396 \\
742 \\
\\
394 \\
510 \\
362 \\
505 \\
169 \\
207 \\
350\end{array}$ & $\begin{array}{r}99 \\
50 \\
\\
\text { unk } \\
100 \\
100 \\
88 \\
30 \\
30 \\
99\end{array}$ \\
\hline \multicolumn{5}{|l|}{ Category II } \\
\hline $\begin{array}{l}\text { 10. Clan Alpine } \\
\text { 11. Gold Butte } \\
\text { 12. Delmar Mountains } \\
\text { 13. East Pahranagat Range } \\
\text { 14. Far South Egan Range } \\
\text { 15. Golden Gate Range } \\
\text { 16. Highland Range } \\
\text { 17. McCullough Mountains } \\
\text { 18. South Pahranagat Range } \\
\text { 19. South Pahroc } \\
\text { 20. South Spring/Bird Spring Mountains } \\
\text { 21. Tobin Range } \\
\text { 22. Virgin Mountains } \\
\text { 23. Worthington Mountains }\end{array}$ & $\begin{array}{l}\text { Nelson } \\
\text { Nelson } \\
\text { Nelson } \\
\text { Nelson } \\
\text { Nelson } \\
\text { Nelson } \\
\text { Nelson } \\
\text { Nelson } \\
\text { Nelson } \\
\text { Nelson } \\
\text { Nelson } \\
\text { Nelson } \\
\text { Nelson } \\
\text { Nelson }\end{array}$ & $\begin{array}{c}30 \\
20 \\
50 \\
50 \\
19 \\
\text { transient } \\
41 \\
80 \\
\text { unk } \\
33 \\
50 \\
44 \\
69 \\
25\end{array}$ & $\begin{array}{l}125 \\
671 \\
759 \\
\text { unk } \\
\text { unk } \\
\text { unk } \\
134 \\
734 \\
574 \\
165 \\
708 \\
339 \\
484 \\
\text { unk }\end{array}$ & $\begin{array}{r}99 \\
99 \\
99 \\
68 \\
99 \\
99 \\
100 \\
99 \\
99 \\
100 \\
97 \\
97 \\
99 \\
95\end{array}$ \\
\hline \multicolumn{5}{|l|}{ Category III } \\
\hline $\begin{array}{l}\text { 24. Bare Mountain } \\
\text { 25. Clover Mountains } \\
\text { 26. Groom Range } \\
\text { 27. Hiko Mountains } \\
\text { 28. Humboldt } \\
\text { 29. Johnie (Last Chance) Range } \\
\text { 30. North Hiko } \\
\text { 31. North Pahranagat Range } \\
\text { 32. North Pahroes } \\
\text { 33. Pancake Range } \\
\text { 34. Seaman Range/Timber Mountain } \\
\text { 35. Sonoma } \\
\text { 36. Wassuk Range } \\
\text { 37. Spector Range } \\
\text { 38. Pilot Range (Nevada/Utah) }\end{array}$ & $\begin{array}{l}\text { Nelson } \\
\text { Nelson } \\
\text { Nelson } \\
\text { Nelson } \\
\text { Nelson } \\
\text { Nelson } \\
\text { Nelson } \\
\text { Nelson } \\
\text { Nelson } \\
\text { Nelson } \\
\text { Nelson } \\
\text { Nelson } \\
\text { Nelson } \\
\text { Nelson } \\
\text { Nelson }\end{array}$ & $\begin{array}{l}0 \\
0 \\
0 \\
0 \\
0 \\
0 \\
0 \\
0 \\
0 \\
0 \\
0 \\
0 \\
0 \\
0 \\
0\end{array}$ & $\begin{array}{l}169 \\
\text { unk } \\
360 \\
117 \\
359 \\
\text { unk } \\
\text { unk } \\
\text { unk } \\
218 \\
110 \\
240 \\
285 \\
125 \\
\text { unk } \\
140\end{array}$ & $\begin{array}{r}50 \\
99 \\
99 \\
100 \\
76 \\
99 \\
99 \\
95 \\
99 \\
100 \\
90 \\
52 \\
95 \\
99 \\
50\end{array}$ \\
\hline
\end{tabular}




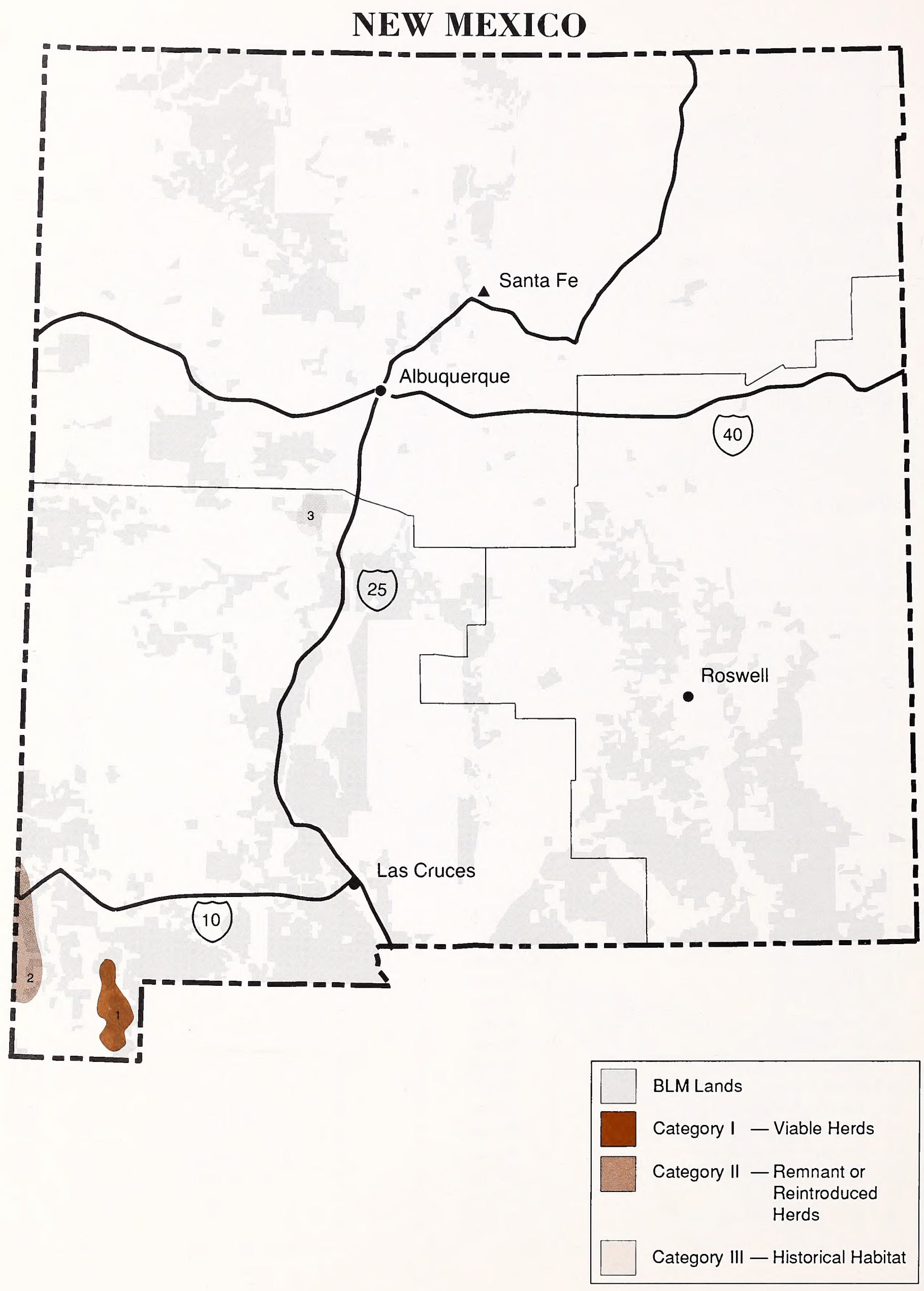




\begin{tabular}{|c|c|c|c|c|}
\hline $\begin{array}{c}\text { New Mexico } \\
\text { Habitat Area }\end{array}$ & Subspecies & $\begin{array}{c}\text { Current } \\
\text { Population } \\
\text { Estimate }\end{array}$ & $\begin{array}{c}\text { Potential } \\
\text { Population } \\
\text { Estimate }\end{array}$ & $\begin{array}{c}\text { Percent } \\
\text { BLM }\end{array}$ \\
\hline $\begin{array}{c}\text { Category I } \\
\text { 1. Big Hatchet/Alamo Hueco/Little Hatchet }\end{array}$ & Mexican & 100 & 400 & \\
\hline \hline $\begin{array}{c}\text { Category II } \\
\text { 2. Peloncillo Mountains }\end{array}$ & Mexican & 30 & 400 & 50 \\
\hline \hline Category III & & & & \\
\hline 3. Ladron Mountains & Mexican & 0 & 130 & 56 \\
\hline
\end{tabular}




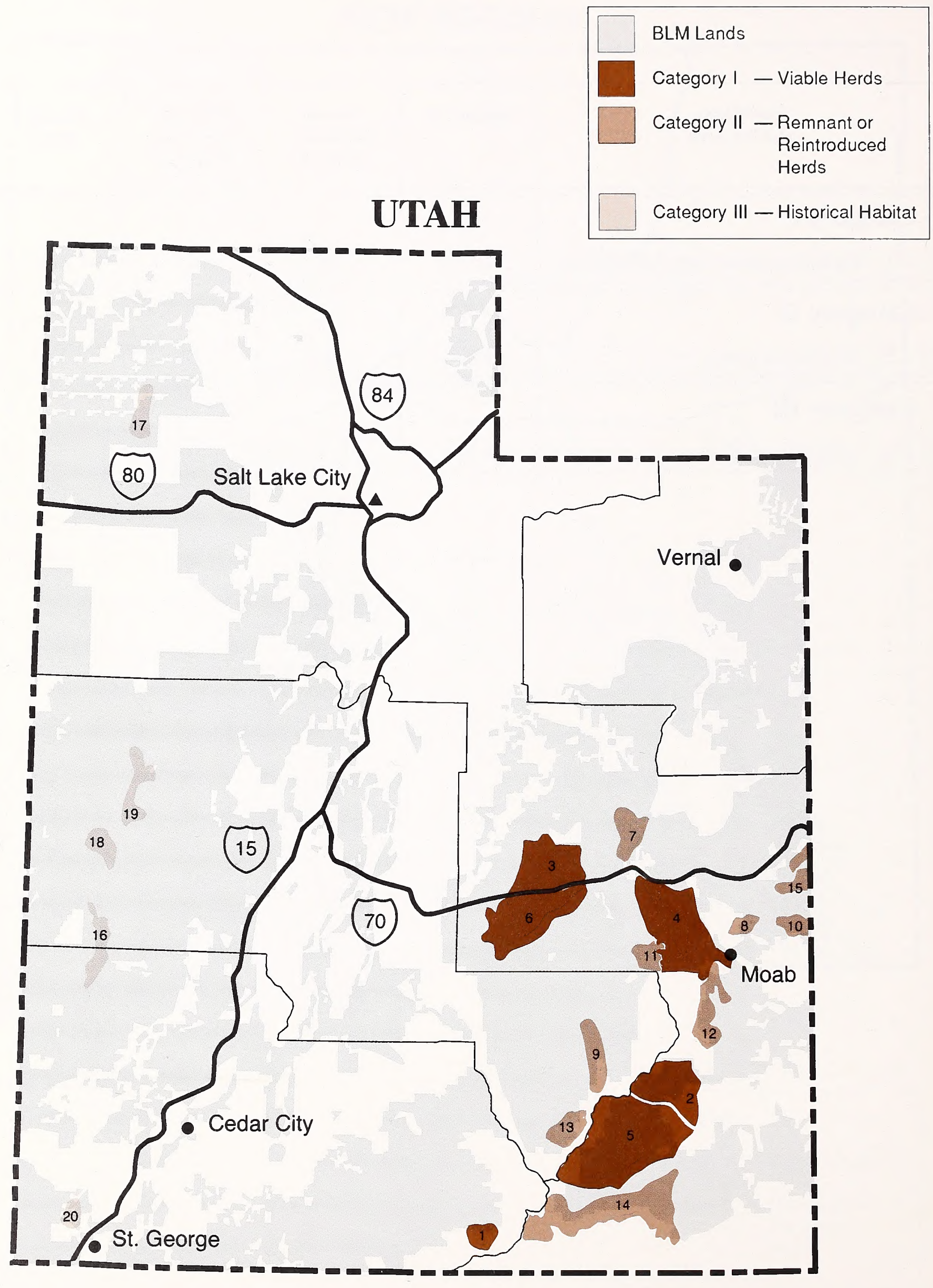




\begin{tabular}{|c|c|c|c|c|}
\hline $\begin{array}{c}\text { Utah } \\
\text { Habitat Area }\end{array}$ & Subspecies & $\begin{array}{l}\text { Current } \\
\text { Population } \\
\text { Estimate }\end{array}$ & $\begin{array}{l}\text { Potential } \\
\text { Population } \\
\text { Estimate }\end{array}$ & $\begin{array}{c}\text { Percent } \\
\text { BLM }\end{array}$ \\
\hline \multicolumn{5}{|l|}{ Category I } \\
\hline $\begin{array}{ll}\text { 1. } & \text { Kaparowitz Plateau } \\
\text { 2. North San Juan } \\
\text { 3. North San Rafael Desert } \\
\text { 4. } \\
\text { 5. } & \text { Sotash } \\
\text { 6. } & \text { South San Juan Rafael Desert }\end{array}$ & $\begin{array}{l}\text { Nelson } \\
\text { Nelson } \\
\text { Nelson } \\
\text { Nelson } \\
\text { Nelson } \\
\text { Nelson }\end{array}$ & $\begin{array}{l}100 \\
556 \\
225 \\
222 \\
834 \\
120\end{array}$ & $\begin{array}{l}150 \\
556 \\
225 \\
222 \\
834 \\
150\end{array}$ & $\begin{array}{l}70 \\
50 \\
89 \\
88 \\
60 \\
90\end{array}$ \\
\hline \multicolumn{5}{|l|}{ Category II } \\
\hline $\begin{array}{l}\text { 7. Beckwith Plateau } \\
\text { 8. Colorado River/Professor Valley } \\
\text { 9. Dirty Devil } \\
\text { 10. Dolores River } \\
\text { 11. Horseshoe Canyon/Bowknot Bend } \\
\text { 12. Kane Springs-Lockhart } \\
\text { 13. Little Rockies } \\
\text { 14. San Juan River } \\
\text { 15. Westwater Canyon }\end{array}$ & $\begin{array}{l}\text { Nelson } \\
\text { Nelson } \\
\text { Nelson } \\
\text { Nelson } \\
\text { Nelson } \\
\text { Nelson } \\
\text { Nelson } \\
\text { Nelson }\end{array}$ & $\begin{array}{l}39 \\
10 \\
25-50 \\
\text { unk } \\
25 \\
50 \\
\text { unk } \\
72 \\
30\end{array}$ & $\begin{array}{l}200 \\
125 \\
\text { unk } \\
250 \\
200 \\
\text { unk } \\
\text { unk } \\
\text { unk } \\
125\end{array}$ & $\begin{array}{r}90 \\
96 \\
\text { unk } \\
96 \\
98 \\
96 \\
96 \\
85 \\
96\end{array}$ \\
\hline \multicolumn{5}{|l|}{ Category III } \\
\hline $\begin{array}{l}\text { 16. Wah Wah Mountains } \\
\text { 17. Newfoundland Mountains } \\
\text { 18. Confusion Mountains } \\
\text { 19. House Range Mountains } \\
\text { 20. Red Mountain }\end{array}$ & $\begin{array}{l}\text { Nelson } \\
\text { Nelson } \\
\text { Nelson } \\
\text { Nelson } \\
\text { Nelson }\end{array}$ & $\begin{array}{l}0 \\
0 \\
0 \\
0 \\
0\end{array}$ & $\begin{array}{l}\text { unk } \\
500 \\
\text { unk } \\
\text { unk } \\
100\end{array}$ & $\begin{array}{l}94 \\
84 \\
92 \\
89 \\
95\end{array}$ \\
\hline
\end{tabular}







\section{DATE DUE}

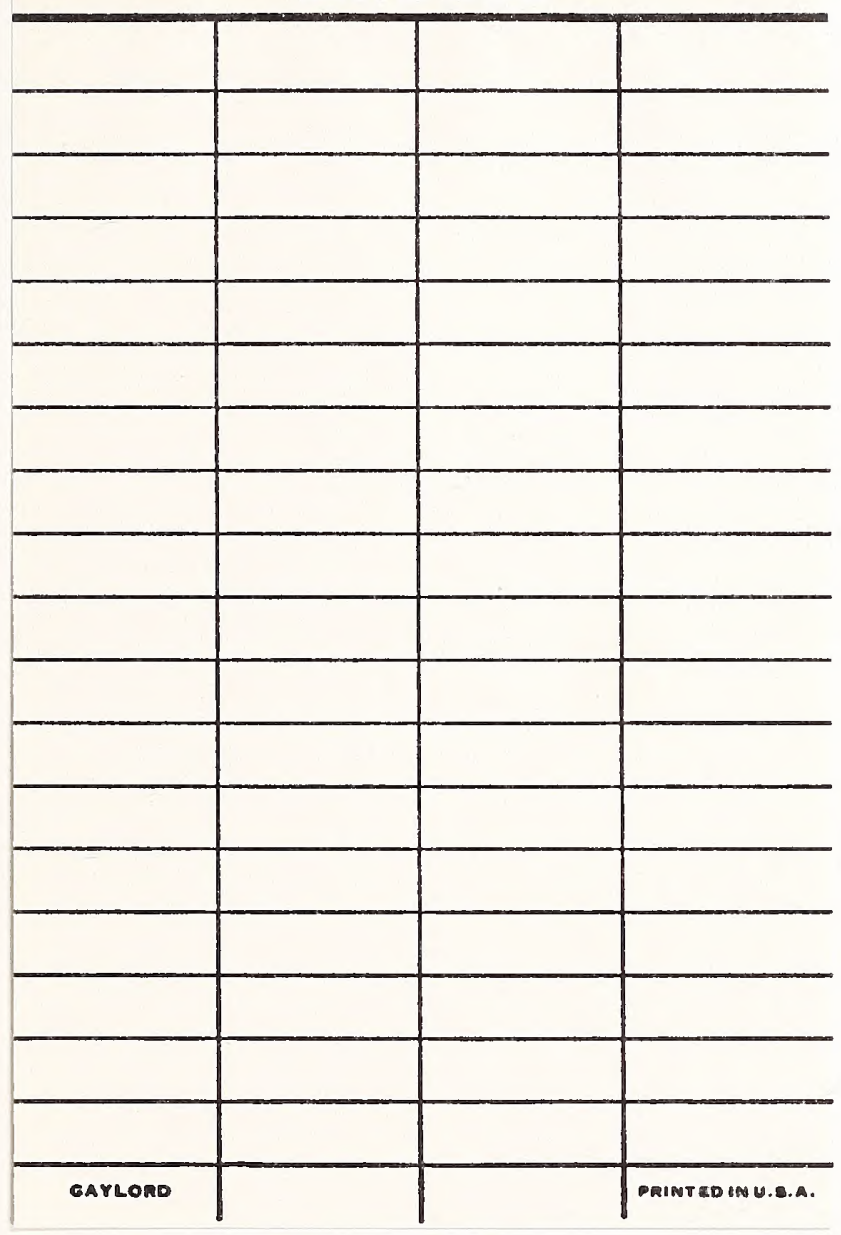

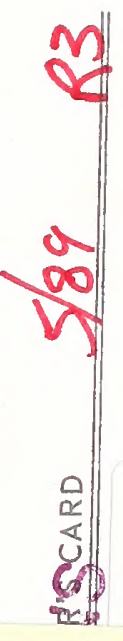

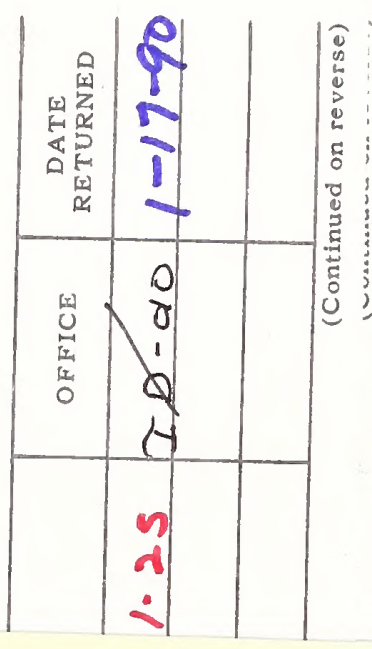

\section{BLM LIBRARY}

SC-324A, BLDG. 50

DENVER FEDERAL CENTER

P. O. BOX 25047

DENVER, CO 80225-0047 

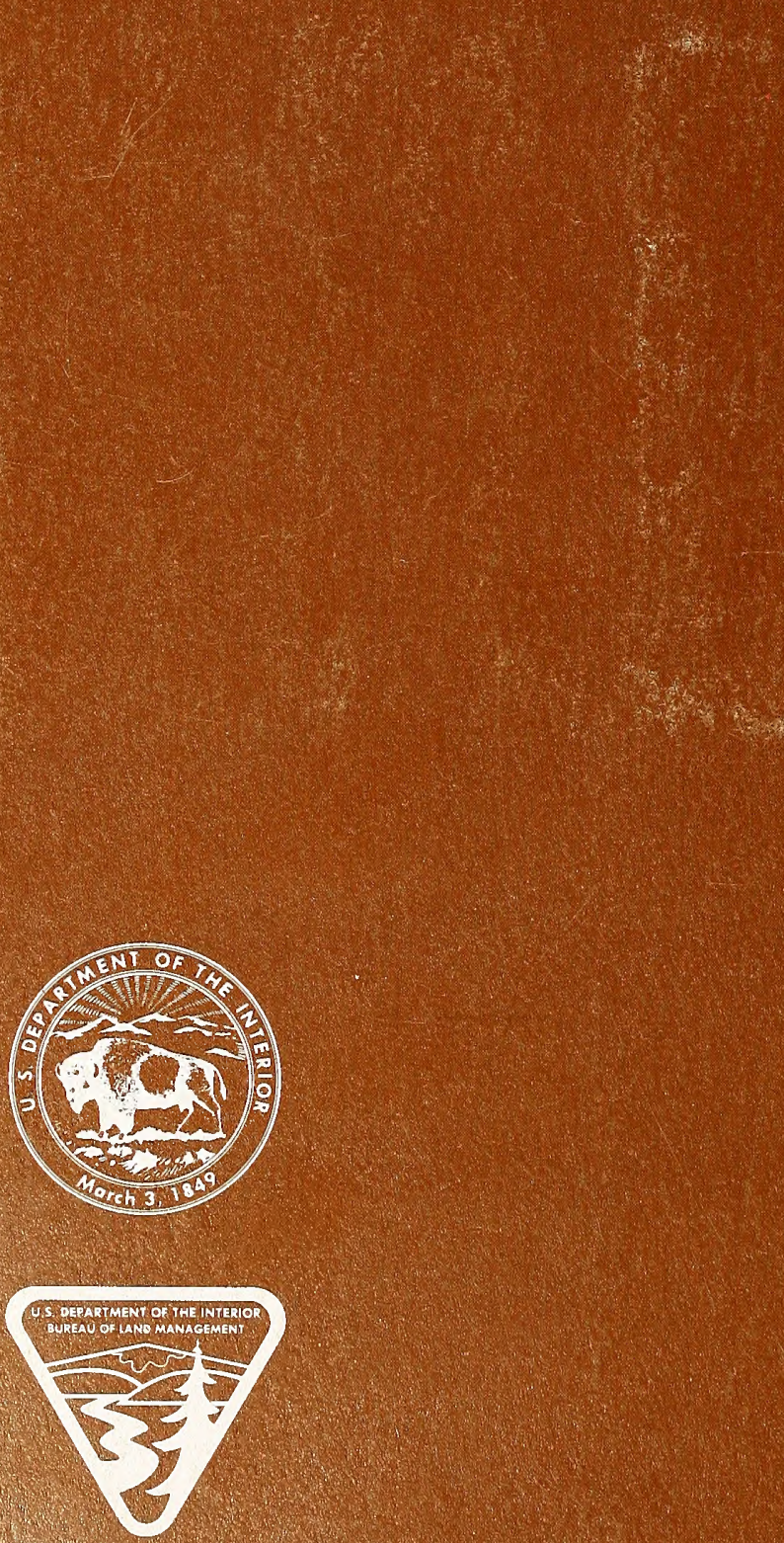